\title{
Tracking rainfall in the northern Mediterranean borderlands during sapropel deposition
}

\author{
Toucanne Samuel ${ }^{1}$, Angue Minto'o Charlie Morelle, Fontanier Christophe ${ }^{1}$, Bassetti Maria-Angela ${ }^{2}$, \\ Jorry Stephan ${ }^{1}$, Jouet Gwenael ${ }^{1}$
}

${ }^{1}$ IFREMER, Laboratoire Environnements Sédimentaires, BP70, 29280 Plouzané, France

${ }^{2}$ CEFREM UMR 5110, Université de Perpignan, 52 Av. P. Alduy, 66860 Perpignan, France

* Corresponding author : Samuel Toucanne, email address : stoucann@ifremer.fr

\begin{abstract}
:
The role of mid-latitude precipitation in the hydrological forcing leading to the deposition of sapropels in the Mediterranean Sea remains unclear. The new GDEC-4-2 borehole, East Corsica margin (northern Tyrrhenian Sea), provides the first precisely dated evidence for enhanced rainfall in the Western Mediterranean during warm intervals of interglacial periods over the last $547 \mathrm{kyr}$. Comparison of GDEC4-2 proxy records with pollen sequences and speleothems from the central and eastern Mediterranean reveals that these pluvial events were regional in character and occurred probably in response to the intensification of the Mediterranean storm track along the northern Mediterranean borderlands in autumn/winter. Our dataset suggests that the timing of maxima of the Mediterranean autumn/winter storm track precipitation coincide with that of the North African summer monsoon and sapropel deposition. Besides highlighting a close coupling between mid- and low-latitude hydrological changes, our findings suggest that during warm intervals of interglacial periods the reduced sea-surface water salinities, together with the high flux of nutrient and organic matter, produced by the monsoonal Nile (and wadi-systems) floods, were maintained throughout the winter by the Mediterranean rainfall. This provides an important additional constraint on the hydrological perturbation causing sapropel formation.
\end{abstract}

\section{Highlights}

- Enhanced autumn/winter Mediterranean rainfall during interglacials. Mediterranean rainfall peaks coincide with maxima of the North African summer monsoon. Rainfall maintain the ocean dilution and the nutrient flux first caused by Nile floods. New constraints on the hydrological perturbation causing sapropel formation.

Keywords : Mediterranean, Rainfall, Interglacials, Sapropel 


\section{INTRODUCTION}

Recent understanding of paleohydrological-paleoclimatic conditions in the Mediterranean is based on the intercomparison of marine, lacustrine and cave records. As a prominent example, the integrated study of sapropel deposits, pollen sequences and speleothems reveals that precession, through its role on both the latitudinal migration of the Intertropical Convergence Zone (ITCZ), the African monsoon variability and the runoff from North Africa into the Mediterranean, has been a fundamental pacer of Mediterranean climate (Lourens et al., 1992; Rohling et al., 2015; Tzedakis, 2007; Tzedakis et al., 2009). Indeed, the intensification of the African summer monsoon during precession-driven northern hemisphere insolation maxima led to extra freshwater input into the Eastern Mediterranean due to enhanced runoff of both the Nile River (Ducassou et al., 2009; Revel et al., 2010; Rossignol-Strick, 1983; RossignolStrick, 1985; Scrivner et al., 2004) and the Central Saharan watershed (e.g., Irharhar, Sahabi and Kufrah rivers; Coulthard et al., 2013; Drake et al., 2011; Larrasoana et al., 2003; Osborne et al., 2008; Rohling et al., 2002; Fig. 1), that in turn caused a disruption in the basin's hydrological cycle, reduced deep-water ventilation and the sapropel deposition (Abu-Zied et al., 2008; Casford et al., 2003; Rohling, 1994; Rohling and Hilgen, 1991; Rohling et al., 2015; Rossignol-Strick, 1985). The sapropel deposition and, by extension, the hydrological cycle in the Mediterranean Sea has long been considered as a low-latitude signal. However, it is wellknown that the atmospheric humidity and precipitation amount also increased over the eastern Mediterranean regions during the sapropel deposition (Milner et al., 2012; Roberts et al., 2006; Rohling, 1994; Rohling and Hilgen, 1991; Rohling et al., 2015; Tzedakis, 2007), as seen in the 250 kyr-long speleothem record for the Soreq Cave, Israel (Bar-Matthews et al., 2003; Bar-Matthews et al., 2000). Interestingly, these speleothems reveal that the isotopic composition of the precipitation over the Eastern Mediterranean during sapropel deposition 
was distinct from African monsoonal composition and had a Mediterranean origin (BarMatthews et al., 2000). This result is supported for the last insolation maxima and sapropel S1 ( 7-9 thousand years ago, ka) by a concomitant humid interval over the Aegean Sea (Kotthoff et al., 2008), in Turkey (Göktürk et al., 2011) and in the northern Red Sea (Arz et al., 2003) that originated from enhancement of rainfall from Mediterranean sources. Similar evidence from northeast Greece and the Tenagghi Philippon peatland were also recently presented for the penultimate interglacial interval [Marine Isotope Stage (MIS) 5] and sapropel S5 ( 125 ka) (Milner et al., 2012; Tzedakis, 2007). These findings definitely challenge the idea for a northward extension of the African monsoon over the Mediterranean basin during insolation maxima. The enhancement of the hydrological activity during sapropel deposition is also recorded in the Western Mediterranean, up to $42-43^{\circ} \mathrm{N}$. The isotopic composition of a stalagmite collected from Antro del Corchia Cave, Central Italy (Zanchetta et al., 2007), and the study of lacustrine and marine sequences from around the Italian Peninsula (Ariztegui et al., 2000; Magny et al., 2013) at the time of Sapropel S1 support this idea. Similar features are observed during sapropel deposition dating from MIS 5e (sapropel S5) and MIS 7a (sapropel S7, $195 \mathrm{ka}$ ) during which significant decrease in salinity occurred in the Eastern Tyrrhenian Sea (Kallel et al., 2000). Results from a stalagmite collected in the Argentarola Cave, Tyrrhenian coast of Italy, also reveal the occurrence of a wet period during the penultimate glacial period (precisely MIS 6d, $\sim 170-180 \mathrm{ka}$ ) that corresponds chronologically to the deposition of sapropel S6 (Bard et al., 2002). Taken together, these evidences highlight that freshwater runoff during sapropel events was not restricted to the Eastern Mediterranean Sea and to the output of both the Nile River and the Central Saharan watershed, but was rather widespread over the entire Mediterranean Sea due to increased rainfall (Bard et al., 2002; Kallel et al., 2000; Kallel et al., 1997). Recent numerical modelling focusing on the time intervals coinciding with the deposition of sapropels also support this assumption (Bosmans et 
al., 2015; Kutzbach et al., 2014). However, relatively few studies are based upon long records that contain multiple precession cycles and intervals for sapropel deposition, especially in the Western Mediterranean. Here, we directly address this gap by studying a high-resolution $\sim 550$ kyr long sedimentary archives from the Northern Tyrrhenian Sea (Figs. 1 to 3), well-known as a highly-sensitive region for paleoclimate reconstructions (e.g., Allen et al., 1999; Bard et al., 2002; Brauer et al., 2007).

\section{MATERIAL AND METHODS}

\subsection{The GDEC-4-2 borehole, East Corsica margin}

This study is based on borehole GDEC-4-2 (N42 $31^{\prime} 23.2$, E9 $\left.42^{\prime} 59.5\right)$, a 125.7 m continuous core (99.9\% recovery) drilled at $492 \mathrm{~m}$ water depth in the Northern Tyrrhenian Sea (Fig. 1) by the R/V 'Bavenit' (FUGRO) during the 2009 GOLODRILL cruise. The GDEC-4-2 borehole was drilled on the upper continental slope of the Golo basin, East Corsica (Fig. 2), directly off the Golo River ( $89 \mathrm{~km}$ long, drainage basin of ca. $1214 \mathrm{~km}^{2}$ ). The Golo is a short, mountainous river (maximum altitude of ca. $2700 \mathrm{~m}$ ), and is an highly efficient sediment routing system (i.e., Golo source-to-sink system), constituting the main sediment source to the adjacent margin (e.g., Calvès et al., 2013; Forzoni et al., 2015; Sømme et al., 2011). The cored interval is composed only of hemipelagic sediments (mainly silty-clay, with some carbonate-rich intervals), and provides a chronostratigraphic framework for East Corsica margins where seismic and sequence stratigraphic organisation are well established (e.g., Calvès et al., 2013 and references therein). The interpretation of high-resolution seismic Sparker lines illustrates the stacking of the last five sedimentary sequences bounded by major discontinuities on the shelf (Fig. 2). The sedimentary sequences are attributed to $100 \mathrm{kyr}$ - 
122 glacio-eustatic cyles, as demonstrated at several margins around the Western Mediterranean

123 (Jouet et al., 2006; Rabineau et al., 2005; Ridente et al., 2009; Sierro et al., 2009). The

124 regressive deposits represent the most significant element constituting upper slope sequences,

125 but the stratigraphic scheme also attests to the presence of transgressive and highstand

126 accumulations, imprinted by stacked continuous and regional seismic reflections representing

127 thick interglacial sedimentary intervals (ca. 10-15 m). Sequence architecture on the upper

128 slope confirms that borehole GDEC-4-2 well records the major sedimentary events that form

129 strata on East Corsica continental margin, in relation to sea-level and climate changes. As no

130 erosion occurred along the recovered interval, it represents a good balance between sediment

131 supply and accommodation space. The well-preserved depositional sequences directly archive

132 the variable influence of the continental supply, at a maximum distance of $15 \mathrm{~km}$ (during

133 highstand conditions) offshore from the Golo river outlet (Fig. 2). This makes borehole

134 GDEC-4-2 well suited for continuously recording sediment input variability from the Golo

135 River and the island of Corsica throughout the last climate cycles.

\subsection{Analytical Methods}

\subsubsection{Sedimentology and Sediment Flux}

140 Physical properties of the GDEC-4-2 borehole which include gamma-ray attenuation density

141 were determined every $1 \mathrm{~cm}$ using a Geotek Multi Sensor Core Logger (MSCL). The

142 borehole was then sampled continuously at 5-20 cm intervals (i.e., 218- to 870-year time

143 resolution). Weight percent $\mathrm{CaCO}_{3}$ were measured on 1412 samples (Figs. 3d and 4). Bulk

144 sediments were acidified with $3 \mathrm{M}$ hydrochloric acid and analyses were performed with an

145 Aquitaine Technique Innovation automated calcimeter. Analytical precision is estimated to be

$146 \pm 2 \%$. Grain-size analyses (Fig. 5d) were performed on 1002 samples using a Coulter LS200 
147 laser microgranulometer with no chemical pre-treatment of the bulk sediment. Micro particle

148 size standard $(15,35,500 \mu \mathrm{m})$ were used as controls to verify the performance of the 149 measurement system. The terrigenous inputs at site GDEC-4-2 were quantified by the

150 calculation of the terrigenous flux or Mass Accumulation Rates $\left(\mathrm{MAR}_{t}\right.$, in $\mathrm{g} . \mathrm{cm}^{-2} \cdot \mathrm{kyr}^{-1}$; Fig. $1515 b)$ according to the following formula: MAR $=$ LSR $\times$ DBD $\times(1$ - carbonate content $)$, with

152 LSR: Linear Sedimentation Rate $\left(\mathrm{cm}^{\mathrm{kyr}}{ }^{-1}\right)$ and DBD: Dry Bulk Density $\left(\mathrm{g} . \mathrm{cm}^{-3}\right)$, which has

153 been calculated assuming a mean grain density of $2.65 \mathrm{~g} . \mathrm{cm}^{-3}$ and an interstitial water density 154 of 1.024 g.cm ${ }^{-3}$ (Cremer et al., 1992) as follows: DBD $=2.65 \times\left(1.024-\mathrm{D}_{\mathrm{wet}}\right) /(1.024-$ 155 2.65). Wet bulk densities $\left(D_{\text {wet }}\right)$ were derived from gamma-ray attenuation density 156 measurements.

\subsubsection{X-Ray Fluorescence Analysis}

159 X-ray fluorescence (XRF) core scanning provides rapid high-resolution records of chemical 160 composition on split sediment cores (Richter et al., 2006). The bulk intensity of major 161 elements for borehole GDEC-4-2 was analysed using an Avaatech XRF core scanner at the 162 Institut Français de Recherche pour l'Exploitation de la Mer (IFREMER), Brest (France).

163 XRF data were collected every $1 \mathrm{~cm}$ along the entire length of the borehole, with a count time 164 of 10 seconds, by setting the voltage to $10 \mathrm{kV}$ (no filter) and the intensity to $600 \mu \mathrm{A}$. Only data for Calcium (Ca) and Titanium (Ti) elements are reported in this study (Figs. 3d, 4 and 5a). It is commonly admitted that elemental $\mathrm{Ti}$ is related to terrigenous-siliciclastic

167 components (clays, heavy minerals), while Ca mainly reflects the carbonate content (calcite

168 and aragonite) in the sediment (Richter et al., 2006). Results are presented in log ratios of 169 element intensities (Weltje and Tjallingii, 2008). 


\subsubsection{Stable Isotopes}

173 Planktonic (920 samples) and benthic (774 samples) foraminiferal ${ }^{18} \mathrm{O} /{ }^{16} \mathrm{O}$ and ${ }^{13} \mathrm{C} /{ }^{12} \mathrm{C}$ ratios

$174\left(\delta^{18} \mathrm{O}\right.$ and $\delta^{13} \mathrm{C}$ respectively, expressed in \%o versus Vienna Pee-Dee Belemnite, VPDB) were

175 measured at the Laboratoire des Sciences de 1'Environnement et du Climat (LSCE), Gif-sur-

176 Yvette (France), on Finnigan $\Delta^{+}$, and OPTIMA and Elementar Isoprime GV mass

177 spectrometers. VPDB is defined with respect to the NBS-19 calcite standard $\left(\delta^{18} \mathrm{O}=-2.20 \%\right.$ o

178 and $\delta^{13} \mathrm{C}=+1.95 \%$ ). The mean external reproducibility $(1 \sigma)$ of carbonate standards is

$179 \pm 0.05 \%$ for $\delta^{18} \mathrm{O}$ and $\pm 0.03 \%$ for $\delta^{13} \mathrm{C}$. Measured NBS-18 $\delta^{18} \mathrm{O}$ is $-23.27 \pm 0.10 \%$ VPDB

180 and measured NBS- $18 \delta^{13} \mathrm{C}$ is $-5.01 \pm 0.03 \%$ VPDB. The three mass spectrometers used for

181 these measurements are calibrated together with respect to NBS-19, NBS-18 and other in-

182 house carbonate standards. The obtained correction does not exceed $0.15 \%$. Measurements

183 were performed on the epipelagic species Globigerina bulloides and Globigerinoides ruber

184 (white) from the 250-315 $\mu \mathrm{m}$ size fraction, the mesopelagic Neogloboquadrina pachyderma

185 (dextral) from the $200-250 \mu \mathrm{m}$ size fraction, and the epifaunal Cibicides wuellerstorfi,

186 Cibicidoides pachyderma and Cibicidoides kullenbergi found in the $>150 \mu \mathrm{m}$ size fraction

187 (Figs. 3c, 3e and 6d). The samples (ca. $50 \mu \mathrm{g}$ minimum) were cleaned in a methanol

188 ultrasonic bath for a few seconds and roasted under vacuum at $380^{\circ} \mathrm{C}$ for 45 minutes prior to

189 analysis, in order to eliminate impurities (Duplessy, 1978). A correction factor of $+1.14 \%$ for

$190 \delta^{18} \mathrm{O}$ was applied to the isotope results from $G$. ruber to account for the relatively constant

191 offset (i.e., vital and habitat preferences) with regard to N. pachyderma and G. bulloides. This

192 correction factor, calculated on 15 paired analyses of $N$. pachyderma and G. ruber, is in

193 agreement with that used for the Upper Pleistocene on ODP 653 and 654, Central Tyrrhenian

194 Sea (Vergnaud-Grazzini et al., 1990). Such a correction factor also allows the alignment of

195 the composite GDEC-4-2 planktonic $\delta^{18} \mathrm{O}$ record onto the $\delta^{18} \mathrm{O}$ G. bulloides record at site

196 MD01-2472 (Fig. 3c) (Toucanne et al., 2012), ca. $15 \mathrm{~km}$ north of site GDEC-4-2. For the 
197 same reasons, a correction factor of $-0.08 \%$ for $\delta^{18} \mathrm{O}$ and of $+0.42 \%$ for $\delta^{13} \mathrm{C}$ (calculated on 9 198 paired analyses of Cibicidoides pachyderma and Cibicides wuellerstorfi, and 21 paired 199 analyses of Cibicidoides kullenbergi and Cibicides wuellerstorfi) was applied to the isotope 200 results from Cibicidoides pachyderma and Cibicidoides kullenbergi with regard to Cibicides 201 wuellerstorfi.

\subsubsection{Benthic Foraminifera Assemblages}

204 A total of 299 sediment samples were analysed for their benthic foraminiferal abundance 205 (Figs. 6b, 6c and 7b). Samples were sieved through a screen with a $150-\mu \mathrm{m}$ mesh, and 206 thereafter the sieve residues were dried in an oven $\left(50^{\circ} \mathrm{C}\right)$. Foraminifera were sorted from 207 dried sediments and stored in Plummer slides. When possible, at least 250 individuals per sediment interval were counted (Murray, 2006). If necessary, samples were divided into subfractions using an Otto splitter. Only 18 intervals presented total foraminiferal stocks comprised between 105 and 249 individuals. In order to reconstruct the paleoenvironmental conditions prevailing at the seafloor, the relative abundance of various ecological assemblages

212 was calculated. First, the relative abundance of foraminiferal species thriving in neritic ecosystems (e.g., Ammonia spp., Elphidium spp., Haynesina spp., Rosalina spp.) (Goineau et al., 2012; Murray, 2006) was determined. Their contribution at our upper-slope site is likely related to downslope transfer by hydrosedimentary processes (e.g., nepheloid layers and

216 turbidity currents from shelf). Therefore, they were removed from foraminiferal census data, 217 and the relative abundance of other species (assumedly autochthonous on the upper slope) 218 was recalculated. Each upper-slope taxon presents a modal bathymetrical distribution which is mainly controlled by the organic matter flux at the seafloor and the bottom water oxygenation 220 (Gooday, 2003; Murray, 2006; Jorissen et al., 2007). Among those taxa, foraminiferal species 221 which can thrive along well-ventilated slope supplied by high organic matter flux were 
regrouped in the 'eutrophic assemblage' (Amphicoryna scalaris, Bolivina spathulata, Bolivina alata, Bulimina marginata, Bulimina costata, Chilostomella spp., Globobulimina spp., Hyalinea balthica, Trifarina angulosa, Valvulineria bradyana, Pseudoclavulina crustata) (De Rijk et al., 2000; Fontanier et al., 2008b; Fontanier et al., 2002; Mojtahid et al., 2009). Note that a special attention was paid to the so-called 'deep infaunal group', which consists of Chilostomella spp. and Globobulimina spp. Both highly specialized taxa are able to live in well-ventilated as well as oxygen-depleted ecosystems where degraded organic detritus accumulates (Abu-Zied et al., 2008; Fontanier et al., 2014; Fontanier et al., 2005).

\section{CHRONOLOGY}

The chronology for GDEC-4-2 was developed by aligning the planktonic $\delta^{18} \mathrm{O}$ (influenced by local hydrography and global ice volume changes) and both the weight percent $\mathrm{CaCO}_{3}$ and $\mathrm{XRF}-\log (\mathrm{Ca} / \mathrm{Ti})$ records (influenced by carbonate productivity and detrital sedimentation) to the NGRIP ice core isotopes from Greenland for the last 60 ka (GICC05 chronology; Rasmussen et al., 2006; Svensson et al., 2008) and to the synthetic Greenland (GL $\mathrm{G}_{\mathrm{T}}$-syn) record of Barker et al. (2011) from 60 to $\sim 550 \mathrm{ka}$ (Table 1 and Fig. 3). The $\mathrm{GL}_{\mathrm{T}}$-syn record was constructed from the EPICA Dome C (East Antarctica) ice core, using the bipolar-seesaw model, and placed on the absolute 'Speleo-Age' (i.e., uranium-thorium based) timescale (Barker et al., 2011). Such an approach was successfully used to produce an accurate longterm chronology on the southwestern Iberian margin (Fig. 3b) (i.e., composite record from cores MD99-2344 and MD99-2343; Hodell et al., 2013; Margari et al., 2014). Previous works at this site have shown that oxygen isotope variability in planktonic foraminifera closely matches the ice core records of temperature over Greenland during the last glacial period (Shackleton et al., 2000), and that prominent lows in $\mathrm{Ca} / \mathrm{Ti}$ correspond to cold stadials in both 
247 the Greenland ice core and the $\mathrm{GL}_{\mathrm{T}}$-syn records (Hodell et al., 2013). We applied the same 248 methodology for GDEC-4-2 because of the striking resemblance between the planktonic $\delta^{18} \mathrm{O}$ 249 and $\mathrm{Ca}$ /Ti records from the Corsican margin with those from the Iberian margin (Figs. 3 and 250 5a). This results from the close linkage of the Mediterranean climate oscillations with North 251 Atlantic climate changes (Cacho et al., 1999; Martrat et al., 2004). The synchronisation of 252 GDEC-4-2 with the synthetic Greenland record reveals that the $125.7 \mathrm{~m}$ long marine 253 sedimentary archive encompasses the last $547 \mathrm{kyr}$ with a mean sedimentation rate of 23 $254 \mathrm{~cm} \cdot \mathrm{kyr}^{-1}$. It corresponds to the highest resolution continuous marine sedimentary archive of 255 the last five climatic cycles in the Mediterranean Sea obtained to date. The placement of the 256 GDEC-4-2 sequence on the speleothem age-scale permits the correlation of the GDEC-4-2 257 sequences to key reference data coming from the Mediterranean (e.g., Bar-Matthews et al., 258 2003; Bar-Matthews et al., 2000; Ziegler et al., 2010) and the North Atlantic (Hodell et al., 259 2013), which are also placed on the speleothem age-scale. Note that the chronology of the 260 uppermost part of GDEC-4-2 is supported by radiocarbon ages performed on shells of 261 planktonic foraminifera (mainly Globigerina bulloides) picked from the bulk sediment (Table 262 2). The ages were corrected for a marine reservoir effect of 400 years, except for those from 263 the period 15-17 ka for which a correction of 800 years was applied (Siani et al., 2001). 264 Radiocarbon ages were calibrated to calendar years using CALIB Rev 7.0.0 (Stuiver and 265 Reimer, 1993) and the IntCal13 calibration curve (Reimer et al., 2013). 


\section{RESULTS AND DISCUSSION}

\subsection{The GDEC-4-2 borehole: a high-resolution record of paleoenvironmental changes in}

\section{the Western Mediterranean}

\subsubsection{Glacial-interglacial climate signature recorded in oxygen isotopes}

273 The prominent features of the marine oxygen isotope records known for the last five climatic 274 cycles (e.g., Hodell et al., 2013; Lisiecki and Raymo, 2005) are reproduced in oxygen isotope measurements from site GDEC-4-2 (Fig. 3c and 3e). The foraminiferal $\delta^{18} \mathrm{O}$ show values 276 ranging from $-0.49 \%$ o $(-1.63 \%$ without correction for $G$. ruber) to $4.11 \%$ for planktonic 277 species [G. bulloides, G. ruber (w) and N. pachyderma (d)], and from $0.75 \%$ to $4.18 \%$ for 278 benthic species (Cibicides wuellerstorfi, Cibicidoides pachyderma and Cibicidoides 279 kullenbergi). These two end-members characterise interglacial (MIS 1, 5, 7, 9, 11 and 13; 280 light isotopes values) and glacial (MIS 2-4, 6, 8, 10 and 12; heavy values) climate conditions, 281 respectively. The glacial-interglacial transitions (i.e., terminations) show significant 282 depletions of ca. 2.0 to $3.5 \%$ o for planktonic oxygen isotopes and of ca. $1.5-2$ to $3 \%$ for 283 benthic signals. The most significant isotopic depletions (for both planktonic and benthic 284 foraminifera) are recorded during the terminations T.I (i.e., transition from MIS 2 to 1, 285 centred at $\sim 15 \mathrm{ka}$ ), T.II (MIS 6-5 transition, $\sim 130 \mathrm{ka}$ ) and T.IV (MIS 10-9 transition, $\sim 337$ 286 ka). Terminations T.III (MIS 8-7 transition, 243 ka), T.V (MIS 12-11 transition, $433 \mathrm{ka}$ ) 287 and T.VI (MIS 14-13 transition, 528 ka) show moderate isotopic depletions in comparison, 288 either due to 'heavy' isotope values for the interglacial periods (e.g., MIS 13c and MIS 7e) or 289 'light' values for the preceding glacial intervals (e.g., MIS 12 and the second part of MIS 8). 290 Such isotopic variability characterizing terminations is observed in the high-resolution 291 planktonic records from the Iberian margin (Hodell et al., 2013) and the Algero-Balearic 
292 Basin (ODP 975; Pierre et al., 1999) (Fig. 3b and 3c). This reveals the regional relevance of 293 the 547-kyr long GDEC-4-2 oxygen isotopes record. Further comparison between the 294 planktonic $\delta^{18} \mathrm{O}$ at these sites highlights that during MIS5, 6 and 7, the GDEC-4-2 site records 295 some pronounced isotopic fluctuations (compared to the ODP 975 planktonic $\delta^{18} \mathrm{O}$ record 296 especially; Fig. 3c), with the same order of magnitude of those recorded during terminations. 297 Indeed, MIS 5 and 7 interglacials show high-amplitude oscillations in the planktonic $\delta^{18} \mathrm{O}$ of 298 ca. 1.5 to $2.7 \%$ (up to $2 \%$ for benthic isotopes) (Fig. 3c). Interestingly, a similar isotope 299 fluctuation (ca. 2.5\% and 1.5\% for planktonic and benthic foraminifera, respectively) is 300 recorded in the first half of glacial MIS 6 (i.e., MIS 6d), with planktonic $\delta^{18} \mathrm{O}$ (down to $0.1 \%$ 301 between 163 and $179 \mathrm{ka}$ ) reaching similar levels to those recorded during MIS 5e (ca. $0 \%$ ) 302 and MIS 7a (0.3\%) and 7c (-0.2\%o). These shifts strongly exceed the attendant sea-level 303 changes related isotopes fluctuations [e.g., ca. 1.0-1.2\% for planktonic oxygen isotopes 304 (Rohling et al., 2014) and ca. $0.87 \%$ to $1.4 \%$ for benthic isotopes (Cacho et al., 2006; 305 Waelbroeck et al., 2002) for a 110-130 m sea-level change]. This suggests that in addition to 306 changes in global ice-sheet volume, the $\delta^{18} \mathrm{O}$ records at site GDEC-4-2 reflect significant 307 surface (and deep water) temperature and/or salinity changes. These changes in surface water hydrography off Corsica closely mirror the climate variability, including recurrent and widespread millennial cooling/warming events during interglacial intervals recognized both 310 on the Iberian margin (Desprat et al., 2006; Hodell et al., 2013; Martrat et al., 2004; Roucoux 311 et al., 2006; Sánchez Goñi et al., 1999) and in the Greenland synthetic record (Barker et al., 312 2011). This strongly supports the direct connection between climate changes at high-latitudes 313 and over the Mediterranean Sea (e.g., Cacho et al., 1999; Martrat et al., 2007). In addition, the 314 subtantial shifts observed in the planktonic $\delta^{18} \mathrm{O}$ between MIS 7e and MIS 5 highlight the 315 direct impact of the precession cyclicity at the GDEC-4-2 site, as previously shown in the central Adriatic (PRAD1-2 borehole; Piva et al., 2008). This astronomical forcing, showing 
prominent fluctuations during these intervals (Berger, 1978; Laskar et al., 2004) and widely

318 observed in the Mediterranean records, is interpreted as a low-latitude signal (Hodell et al., 2013; Lourens et al., 1992; Sánchez Goñi et al., 2008; Tzedakis, 2007). Taken together, this confirms that the Corsica Trough and the northern Tyrrhenian Sea are climatically sensitive regions of the Mediterranean Sea (e.g., Hayes et al., 2005; Kuhlemann et al., 2008; Toucanne et al., 2012).

\subsubsection{Sediment supplies and the ' $\mathrm{CaCO}_{3}$ paradox'}

Sedimentation at site GDEC-4-2 shows the alternation of silty-clay and carbonate-rich (i.e.,

$\mathrm{CaCO}_{3}>30 \%$ ) silty-clay deposited by hemipelagic processes. The carbonate content on the upper continental slopes is generally controlled by the surface-water carbonate productivity and the dilution by terrigenous sediments (Cremer et al., 1992; Hoogakker et al., 2004). Downcore fluctuations of the weight percent $\mathrm{CaCO}_{3}$ at site GDEC-4-2 range from 7 to $45 \%$ and follow the local (i.e., site GDEC-4-2) and regional (i.e., ODP 975 and combined record of core MD01-2444 and MD01-2443) $\delta^{18} \mathrm{O}$ records, with generally higher (lower) weight 332 percent $\mathrm{CaCO}_{3}$ during interglacial s.l. (glacial) periods. This carbonate signal is wellcorrelated with the high-resolution XRF $\log (\mathrm{Ca} / \mathrm{Ti})$ record $(r=0.91 / \mathrm{p}<0.01$; Fig. 4) that reflects varying proportions of biogenic $(\mathrm{Ca})$ and detrital (Ti) sediment supply (Richter et al., 2006). Besides confirming that $\log (\mathrm{Ca} / \mathrm{Ti})$ provides a reliable proxy for weight percent

$336 \mathrm{CaCO}_{3}$ (Hodell et al., 2013), our results reveal that glacial-interglacial $\mathrm{CaCO}_{3}$ cycles in the 337 Northern Tyrrhenian Sea (Fig. 3d) are similar to those found in the Atlantic Ocean (e.g., 338 Balsam and McCoy, 1987; Helmke and Bauch, 2001; Ruddiman, 1971). In the Western 339 Mediterranean, this variability on glacial-interglacial time scales is assumed to reflect variable 340 dilution by clays (see Hoogakker et al., 2004 for a thorough discussion). During glacial 341 intervals, cold and dry climatic conditions (i.e., low vegetation cover and enhanced soil 
erodibility) combined with a lowered sea level (i.e., closeness of the sediment source)

343 promote enhanced fluvial input to the sea (Blum and Törnqvist, 2000; Bonneau et al., 2014;

344 Hoogakker et al., 2004). Such a pattern has been described for the Golo River for the last

345 glacial period (Calvès et al., 2013), and is illustrated for the last 547 kyr by the calculation of

346 the terrigenous flux at site GDEC-4-2 (Fig. 5b). The latter reveals generally higher riverine

347 input during glacials (sea-level lowstands, $\leq-60 \mathrm{~m}$ relative to the present day) and lower input

348 during interglacials s.l. (sea-level highstands, $\geq-60 \mathrm{~m}$ ). This also confirmed by the close

349 correlation between the terrigenous flux and the XRF $\log (\mathrm{Ti} / \mathrm{Ca})$, a reliable proxy for river

350 discharge (e.g., Arz et al., 1998; Toucanne et al., 2009) (Fig. 5c). Thus, the variability in the

351 terrigenous flux explains the glacial-interglacial periodicity observed in the carbonate content

352 at site GDEC-4-2. The reliable agreement between the variations in $\log (\mathrm{Ca} / \mathrm{Ti})$ at site GDEC-

353 4-2 and those recorded on the Iberian margin (Fig. 5a), where variations in weight percent

$354 \mathrm{CaCO}_{3}$ are ascribed to variable dilution by terrigenous input (Hodell et al., 2013; Thomson et

355 al., 1999), strengthens our interpretation.

356 Surprisingly, some weight percent $\mathrm{CaCO}_{3}$ and $\log (\mathrm{Ca} / \mathrm{Ti})$ lows are observed during 357 interglacials s.s. (i.e., MIS 5e, MIS 7c and 7e, MIS 9e, MIS 11, MIS 13c; Figs. 3d, 5a, 7c and 358 8d) with the exception of MIS 1 . Both weight percent $\mathrm{CaCO}_{3}$ and $\mathrm{Ca} / \mathrm{Ti}$ ratios show only 359 moderate values during MIS 1, precisely between 7.5 and $10 \mathrm{ka}$, and higher carbonate level 360 are described thereafter. Weight percent $\mathrm{CaCO}_{3}$ and $\log (\mathrm{Ca} / \mathrm{Ti})$ lows observed during 361 previous interglacials s.s. coincide with both the lightest values of the local planktonic $\delta^{18} \mathrm{O}$, 362 and sea-surface temperature peaks (ca. $19-23^{\circ} \mathrm{C}$ ) on the Iberian margin and in the Alboran Sea 363 (Martrat et al., 2007; Martrat et al., 2014) (Figs. 5e,f and 8e,f,g). They usually follow (with 364 the exception of MIS 9d) an abrupt millennial $\mathrm{Ca} / \mathrm{Ti}$ increase that occurs at the end of the 365 termination (e.g., T.V and T.VI) or during the first millennia of the interglacial s.s. (e.g., MIS 366 5e, MIS 7e). These carbonate content lows, also observed during the successive warm 
intervals that follow the interglacials s.s. (e.g., MIS 5c, MIS 7c, MIS 13a), precede maxima in

$368 \mathrm{Ca} / \mathrm{Ti}$ values. The latter are observed either at the transition between the interglacials s.s. and 369 the subsequent millennial cooling events (e.g., MIS 7e-7d transition) or during these cooling events (e.g., MIS 5d, MIS 9d). The carbonate content at site GDEC-4-2 during interglacials s.s. thus follows an M-shape pattern that is particularly well-expressed during MIS 5e, MIS7e and MIS11 (Figs. 3d, 5a, 7c). This feature is unexpected considering both the carbonate 373 productivity and the amount of sediment delivery to the Western Mediterranean Sea during 374 interglacial periods. Indeed, interglacial conditions favoured the biogenic carbonate productivity in the Western Mediterranean Sea (Hoogakker et al., 2004) (see Fig. 3d, core LC06, for MIS 5), and the input of river-derived clays to continental margins usually reached a minima at that time. This is primarily caused by the development of the vegetation which tends to increase the stability of soil, and highstand conditions of sea level which favoured the trapping of river sediment inputs on the inner continental shelves (Blum and Törnqvist, 2000). Thus, these conditions (i.e., high carbonate productivity and low dilution by clays) explain the high carbonate content observed in the Balearic Abyssal Plain (Hoogakker et al., 2004) (Fig. 382 3d) and on the Iberian margin (Hodell et al., 2013) (Fig. 5a) during interglacial conditions. 383 Our data point out a ' $\mathrm{CaCO}_{3}$ paradox' on the East Corsica margin during these intervals. For 384 illustrating this ' $\mathrm{CaCO}_{3}$ paradox' we compare $\mathrm{Ca}$ /Ti values at site GDEC-4-2 with those of the 385 Iberian margin (Hodell et al., 2013) (Fig. 5a). Strong differences in the carbonate content are 386 observed in these two sites at time of interglacial warm intervals and especially during 387 interglacials s.s. (e.g., MIS 5a, 5e; MIS 7a, 7c, 7e; MIS 9a, 9c, 9e; MIS 11). This 'CaCO 3 388 paradox' is solved through the quantification of the terrigenous flux (Fig. 5b). It reveals that 389 (i) input of Golo-derived clays did not reach a minimum at the time of the interglacials s.s. but 390 during the second half of the interglacial periods s.l. (e.g., MIS 5c, MIS 7d, MIS 9c-d), and 391 (ii) except for MIS 1, interglacials s.s. sediment flux were equivalent to (or even exceeded; 
see MIS 7c and MIS 11) those observed during the preceding glacial interval. This indicates that the Golo River activity during interglacials s.s. was important enough to produce unexpected high terrigenous flux at site GDEC-4-2 despite the sea-level highstand conditions. The carbonate content lows observed during interglacials s.s. and more generally during warm intervals of interglacial periods thus result from a dilution effect by the Golo River terrigenous input. The latter is also confirmed by concomitant increases of the silt fraction at site GDEC-4-2 (Fig. 5d). The evolution of the silt fraction over the studied interval closely matches the $\mathrm{Ti} / \mathrm{Ca}$ ratios, thus reinforcing their interpretation as proxies for river discharge.

\subsubsection{Benthic foraminifera assemblages and carbon isotopes}

Benthic foraminifera assemblages and carbon isotopes are used to test the assumption described above for enhanced Golo River discharges during warm intervals of interglacial periods. The relative abundance of the foraminiferal eutrophic group gives reliable insights regarding the Golo River input and the surface-water productivity exported to our bathyal site. Indeed, the relative contribution of the eutrophic species varies over the last $547 \mathrm{kyr}$ in phase with the glacial-interglacial variability (Fig. 6b). Higher abundances of the eutrophic group (abundance of up to $60-80 \%$ ) are generally found during glacials compared to interglacial s.l. periods. This variability likely results from the sea-level variability, with sea-level lowstand conditions enhancing deposition of terrestrial organic matter supplied by the Golo River on the upper slope. Moreover, the depth-dependant exported productivity may increase significantly when sea level is close to the shelf break, which induces a likely increase of eutrophic group abundance. This relationship between the foraminiferal faunas and eustatic changes is corroborated by the highest abundance of the foraminiferal eutrophic group recorded during MIS12 (Fig. 6b), that corresponds to the most extreme lowstand conditions recognized for the last climatic cycles (Grant et al., 2014; Waelbroeck et al., 2002). Minima in 
the abundance of the eutrophic group (ca. 20\%) do not coincide strictly with the interglacials

418 s.s. and the attendant sea-level highstand conditions, but match with the second part of the 419 interglacials s.l., following the same pattern of sediment flux as described above. In contrast, 420 some peaks in the abundance of the eutrophic taxa (ca. 50-70\%; i.e., equivalent or higher than 421 that observed during glacials) are also recorded at the beginning of the interglacials (e.g., 422 MIS1, MIS5e, MIS7c, MIS9e). It suggests that significant input of organic matter occurs at 423 GDEC-4-2 site during these periods of sea-level highstand. Such an exportation of organic matter may be related to enhanced discharge of the Golo River and the increase of productivity exported to the seabed. This assumption is supported by the concomitant increase in the abundance of the deep infaunal group composed of Chilostomella spp. and Globobulimina spp, both species being known to proliferate in oxygenated ecosystems where organic detritus focuses (Fontanier et al., 2014; Fontanier et al., 2005; Fontanier et al., 2008a). The benthic $\delta^{13} \mathrm{C}$ at site GDEC-4-2 relies mainly on Cibicidoides pachydermus $\left(\delta^{13} \mathrm{C}_{C p}\right)$ and

430 Cibicidoides kullenbergi $\left(\delta^{13} \mathrm{C}_{C k}\right)$ (Fig. 6d) which are shallow infaunal species (Eberwein and 431 Mackensen, 2006; Fontanier et al., 2002; Fontanier et al., 2013). Their $\delta^{13} \mathrm{C}$ signatures, 432 primarily constrained by the $\delta^{13} \mathrm{C}$ of bottom water (ca. $0.9 \%$ for the modern Levantine 433 Intermediate Water -LIW- in the Western Mediterranean Sea; Pierre, 1999), shift to lower 434 values in relation to organic detritus mineralization within the sediment (e.g., Eberwein and 435 Mackensen, 2006; Fontanier et al., 2006a; Schmiedl et al., 2004). In other words, both the 436 modern $\delta^{13} \mathrm{C}_{C p}$ and $\delta^{13} \mathrm{C}_{C k}$ signals echo the $\delta^{13} \mathrm{C}_{\text {DIC }}$ of pore water, which are likely depleted 437 during early diagenesis compared to the $\delta^{13} \mathrm{C}$ of bottom water. For instance, offsets ranging 438 between $-0.3 \%$ and $-0.6 \%$ were documented between the $\delta^{13} \mathrm{C}_{\text {DIC }}$ of bottom water and $\delta^{13} \mathrm{C}_{C p}$ 439 (Fontanier et al., 2006b; Schmiedl et al., 2004). For C. kullenbergi, offsets between -0.3 and $440 \quad 0.5 \%$ were recorded by Griveaud (2007) and Licari and Mackensen (2005). We have 441 arbitrarily inserted the higher above-mentioned thresholds of $-0.6 \%$ related to the modern 
$442 \delta^{13} \mathrm{C}_{\mathrm{DIC}}$ of pore water in Figure 6d. Depletions of both $\delta^{13} \mathrm{C}_{C p}$ and $\delta^{13} \mathrm{C}_{C k}$ signals above this

443 limit (i.e., threshold of $0.3 \%$; and $0.9 \%$ for $\delta^{13} \mathrm{C}_{C w}$ ) are recorded throughout our record,

444 especially during warm interglacial intervals and during the glacial MIS 6d. These events

445 occur simultaneously with high abundances of the deep infaunal group (ca. 10 to $40 \%$ ),

446 supporting a higher rate of in-sediment organic matter mineralization in response to enhanced

447 input of organic detritus during these periods. We assume that the synchronicity of benthic

$448 \delta^{13} \mathrm{C}$ depletions and peaks in the abundance of eutrophic and deep infaunal foraminifera, 449 coupled with concomitant peaks in terrigenous input, supports the assumption for enhanced 450 Golo River discharges during warm intervals of interglacial periods (interglacials s.s. 451 especially) and during the glacial MIS 6d.

4.2 Correlation with Mediterranean records and paleoclimatic implications

\subsubsection{Local to regional significance of the rainfall events recorded over Corsica}

Our result suggesting enhanced Golo River discharges during interglacial warm intervals (interglacials s.s. especially) and the glacial MIS 6d implies a significant increase in precipitation amount over Corsica. This assumption is strongly supported through the correlation between the GDEC-4-2 proxy records for river discharge and paleoclimatic records from the Italian Peninsula and its surrounding seas. Indeed, increased flux of continental materials (i.e., sediment and organic matter) at site GDEC-4-2 correlate with

462 prominent negative $\delta^{18} \mathrm{O}$ excursions in both the Sulmona basin (Central Italy; Regattieri et al., 463 2015) and the Argentarola (Tyrrhenian coast of Italy; Bard et al., 2002), Antro del Corchia 464 and Tana Che Urla (Central Italy; Drysdale et al., 2005; Regattieri et al., 2014; Zanchetta et al., 2007) cave speleothems (Fig. 7a), and with salinity decreases in the central Adriatic basin 466 (Piva et al., 2008) and in the Eastern Tyrrhenian Sea (Kallel et al., 2000). This indicates that 
the high runoff recorded for the Golo River during warm intervals of interglacial periods

468 (interglacials s.s. especially) and the glacial MIS 6d likely originate from enhanced regional

469 rainfall. Such 'pluvial' conditions explain the ca. 1.5 to $2.7 \%$ depletions observed in the

470 planktonic $\delta^{18} \mathrm{O}$ during MIS 5 and MIS 7 (Figs. 3c, 5f and 6a). As a result, the GDEC-4-2

471 borehole can be seen as a valuable record for rainfall variability in the Western

472 Mediterranean.

473 The comparison of our results with paleoclimatic records located further east suggests a wider

474 significance for the GDEC-4-2 'runoff/rainfall' record presented here. The comparison of the

475 GDEC-4-2 proxy records for river discharge with the 250-kyr composite isotopic record of

476 speleothems from the Soreq and Peqiin caves (Israel) reveals that periods characterised by

477 increased Corsican runoff since MIS 7 (i.e., MIS1, MIS 5a, 5c, 5e; MIS 6d; MIS 7a, 7c, 7e)

478 coincide with high rainfall regimes (i.e., low $\delta^{18} \mathrm{O}$ ) in the eastern Mediterranean region (Fig.

479 7a) (Ayalon et al., 2002; Bar-Matthews et al., 2003). The runoff increase recorded at site

480 GDEC-4-2 during MIS 5e is also synchronous with a significant salinity decrease at site

481 KS205, northwest Ionian Sea (Fig. 8e) (Rohling et al., 2002). In agreement with the

482 conclusions of Bard et al. (2002) for MIS 6 and Kallel et al. (2000) for the 200-60 ka interval,

483 this shows that both western and eastern Mediterranean basins experienced simultaneously

484 wetter conditions over the last $250 \mathrm{ka}$, precisely during interglacial warm intervals

485 (interglacials s.s. especially) and the glacial MIS 6d. The lack of pre-MIS 7 speleothem-based

486 rainfall records in the Eastern Mediterranean precludes a robust inter-basin comparison for the

487 basal part of the GDEC-4-2 borehole. Nevertheless, the above correlation for the last $250 \mathrm{ka}$

488 as well as palynological evidence showing relatively high water availability during

489 interglacials in Northern Greece (Fig. 7f) (Tenaghi Philippon; Tzedakis et al., 2006; Tzedakis

490 et al., 2009) and in Northern Levant (Yammouneh sequence; Gasse et al., 2014) encourages

491 us to identify the GDEC-4-2 events (high -silty- terrigenous input, high abundance of 
492 foraminiferal eutrophic and deep infaunal taxa, and benthic $\delta^{13} \mathrm{C}$ depletions) over the 547493 250-kyr period as pluvial episodes over the Mediterranean basin (Fig. 6). As a result, we 494 assume that Mediterranean 'pluvial' phases also occurred during MIS 9 (MIS 9e especially), 495 MIS 11 and MIS 13 (MIS 13a and 13b) (Figs. 3, 5 and 6). This highlights interglacial 'pluvial' 496 periods as a distinctive feature of the Mediterranean climate (Bar-Matthews et al., 2003) and 497 confirms that (minima in) precession (i.e., winter insolation minima and summer insolation 498 maxima) has been a pacemaker for rainfall variability in the Mediterranean basin (e.g., 499 Lourens et al., 1992; Sánchez Goñi et al., 2008; Tzedakis, 2007). The trend in the evolution of 500 the GDEC-4-2 proxy records for river discharge (especially the terrigenous fluxes and the 501 abundance of the deep infaunal foraminifera) also attests to the impact of eccentricity 502 modulation of precession (and insolation) on the runoff/rainfall activity. Indeed, maxima of 503 the 100-kyr eccentricity cycles correlate with periods of highest Golo River discharge (Figs. $6 \mathrm{c}$ and $7 \mathrm{~b})$. This astronomical forcing, previously identified as a pacemaker for annual rainfall (Sierro et al., 2000) and lake-level fluctuations in Neogene sequences of the Western Mediterranean (Abels et al., 2009; Valero et al., 2014; Van Vugt et al., 2001), likely explains the significant difference in amplitude of the Golo River discharges between MIS 1 (lowamplitude), MIS 5e (moderate to high) and MIS 7c (very-high) for example.

\subsubsection{Source and timing of Mediterranean rainfall events recorded at the GDEC-4-2 site}

511 The Mediterranean pluvial phases recorded at site GDEC-4-2 (as well as in the Israeli 512 speleothems over the last 250 kyr; Bar-Matthews et al., 2003) are synchronous with increased river runoff from the Libyan-Egyptian sector of North Africa. This is nicely illustrated at

514 high-resolution for MIS 5e through the comparison between the GDEC-4-2 proxy records for 515 river discharge and the G. ruber $\delta^{18} \mathrm{O}$ record of ODP 967 and ODP 971 (Fig. 8f,g) located 516 close to the outflow of the Nile and the Libyan river systems, respectively (Rohling et al., 
2002). For the last climatic cycles, the relationship between Mediterranean 'pluvial' phases

518 and the runoff from North African rivers is supported by the correlation between the GDEC4-2 dataset and the XRF Ba/Al ratio from ODP 968 (Fig. 7d) (Eastern Mediterranean; Ziegler et al., 2010) that reveals that the timing of 'pluvial' phases coincides with that of sapropel 521 deposition. Indeed, the sapropel deposition, as a direct consequence of a profound disruption 522 in the basin's hydrological cycle, is directly linked to increased river summer floods from the 523 Central Saharan watersheds (e.g., Irharhar, Sahabi and Kufrah rivers; Fig. 1) and the Nile River (Larrasoana et al., 2003; Osborne et al., 2008; Rohling et al., 2002; Rohling and Hilgen, 1991; Rossignol-Strick, 1985; Rossignol-Strick et al., 1982; Scrivner et al., 2004). Increased summer floods from the Nile and Central North African rivers are linked to the intensification and northward extension of the African summer monsoon at time of minima in the precession index (i.e., during northern hemisphere summer insolation maxima), but the monsoon rains only penetrate to $25^{\circ} \mathrm{N}$ (Rohling et al., 2002; Rohling and Hilgen, 1991; Tuenter et al., 2003; Tzedakis, 2007). In addition, terrestrial pollen sequences from Italy, Greece, Turkey and the Levant reveals the expansion of Mediterranean sclerophyllous vegetation, indicative of 532 increased summer aridity, in the northern Mediterranean borderlands during interglacial 533 sapropel deposition (Milner et al., 2012; Tzedakis, 2007; Tzedakis et al., 2003) (see Fig. 8c for MIS 5e and the Sapropel S5 deposition). Taken together, these results suggest that the Mediterranean 'pluvial' events recorded at site GDEC-4-2 probably occurred in autumn/winter

536 (i.e., during winter insolation minima) (Bosmans et al., 2015; Fletcher and Sánchez Goñi, 537 2008; Kotthoff et al., 2008; Rohling et al., 2015; Sánchez Goñi et al., 2008; Tzedakis, 2007).

538 This is supported for the last interglacial by pollen-based climate reconstructions of 539 temperature and precipitation seasonality from Lake Accesa (Italy), ca. $100 \mathrm{~km}$ east of site 540 GDEC-4-2 (Peyron et al., 2011). These 'pluvial' events probably originated from the 541 cyclogenesis mechanisms in the Mediterranean (Reale et al., 2001; Trigo et al., 2002; Trigo et 
542 al., 1999). Nowadays, the northern Mediterranean borderlands (including, from west to east:

543 site GDEC-4-2, the Corchia and Argentarola caves, the KS205 marine record, the terrestrial 544 pollen sequences cited above and the Soreq and Peqiin caves) are under the influence of the 545 autumn/winter (i.e., October-March) Mediterranean storm track, with the Gulf of Genoa and 546 the Aegean Sea consisting of two of the most active cyclogenetic regions in the 547 Mediterranean realm. The cyclogenesis over these regions can occur consecutively as the 548 result of the same major synoptic system, usually of North Atlantic origin, crossing central 549 Europe (Trigo et al., 2002; Trigo et al., 1999). We showed previously that enhanced 550 interglacial runoff of the Golo River, interpreted as enhanced rainfall over Corsica, coincides 551 with the maximum rainfall amount in Israel (Bar-Matthews et al., 2003). By considering both 552 the Mediterranean origin of the Levant precipitation (Bar-Matthews et al., 2003; Bar553 Matthews et al., 2000) and the pollen-based reconstructions of precipitation seasonality in the 554 northern Mediterranean borderlands (Milner et al., 2012; Peyron et al., 2011; Tzedakis, 2007), 555 we thus assume that the GDEC-4-2 sequence records the upstream activity of the 556 autumn/winter Mediterranean storm track over the last 547 kyr. In other words, the GDEC-45572 borehole is the first sequence containing multiple precession cycles that highlights enhanced 558 autumn/winter rainfall over the northern Mediterranean borderlands during interglacial warm 559 intervals, in particular during interglacials s.s. Our results support recent modelling 560 experiments showing increased winter precipitation in regions between $30^{\circ} \mathrm{N}$ and $45^{\circ} \mathrm{N}$ over 561 the Mediterranean and Middle East during periods of maximum orbitally-forced insolation 562 seasonality (Kutzbach et al., 2014). Our results also reconcile the speleothem-based snapshots 563 for rainfall activity in the northern Mediterranean borderlands during interglacial warm 564 intervals (Bar-Matthews et al., 2003; Bar-Matthews et al., 2000; Drysdale et al., 2005; 565 Göktürk et al., 2011; Zanchetta et al., 2007) with the incongruent evidence (i.e., increased - 
summer- aridity during interglacial s.s.) from long-term pollen sequences (see Tzedakis, 2007

567 for a thorough review).

\subsubsection{Rainfall events over the northern Mediterranean borderlands and the African}

\section{monsoon}

571 The above lines of evidence highlight a direct relationship between the rainfall variability

572 over the northern Mediterranean borderlands and the precession forcing. By considering the

573 long-known link between the precession forcing and the low-latitude climate (e.g., Hilgen, 1991; Rossignol-Strick, 1985; Trauth et al., 2009; Tzedakis et al., 2009), we can hypothesize strong teleconnections between the Mediterranean storm track (and more generally the mid-

576 latitude atmospheric circulation pattern) and the monsoon activity. The coincidence in the

577 timing of the increased Mediterranean (autumn/winter) storm track precipitation with that of the North African (summer) monsoon during warm intervals of interglacial periods, shown by the correlation of 'pluvial' events over Corsica and the increased runoff of the Nile River (Figs. 7 and 8), highlights a close link between mid- and low-latitude hydrological changes.

581 Moreover, these climatic events coincide with increased rainfall over East Asia in response to 582 enhanced (summer) monsoon (Fig. 7e) (Jo et al., 2014; Wang et al., 2008). The concomitant 583 changes in the precipitation patterns over the northern Mediterranean borderlands, the North 584 Africa continent and East Asia likely reflect shifts in the mean latitudinal position of the 585 ITCZ, with an attendant climatic response at mid-latitudes.

586 This relationship between mid- and low-latitude hydrological changes is nicely depicted for

587 Southern Europe and North Africa at centennial to millennial time-scale during MIS 5e, 588 especially between ca. 121 and 129 ka (Fig. 8). During this period of enhanced summer monsoon over North Africa, a sustained (ca. 800 yr) relaxation of the ITCZ penetration

590 leading to a monsoon disruption occurred at around 124-125 ka (after alignment on the 
speleothem age-scale; Rohling et al., 2002). At the same time, while enhanced winter rainfall

592 dominates over the 122-127 kyr interval, a sustained decrease in riverine inputs occurred off

593 Corsica (Fig. 8d). This short-lived event, accompanied by a ca. 2\%o increase of the G. ruber

$594 \delta^{18} \mathrm{O}$ in the Ionian Sea (Fig. 8e) (Rohling et al., 2002), highlights a reduction in the winter

595 precipitation and, by extension, a decrease of the Atlantic-Mediterranean cyclogenesis

596 activity. This close relationship between the ITCZ motion, the North Africa summer monsoon

597 and the rainfall activity over the northern Mediterranean borderlands, evident for the whole

598 interval (i.e., 121-129 ka; Fig. 8), points out a positive correlation between the intensity of the

599 North African summer monsoon and the cyclogenesis activity in the Mediterranean Sea (i.e.,

600 the stronger the North Africa summer monsoon, the stronger the Mediterranean winter

601 rainfall). This indicates that climate conditions over North Africa and the Mediterranean in

602 summer could possibly force the cyclogenesis activity on the northern Mediterranean

603 borderlands during the successive winter. At present, it is well-known that the northward shift

604 of the ITCZ over North Africa during summer (with the associated reinforcement of the

605 Hadley circulation and the eastwards expansion of the Azores subtropical high) induces hot

606 and dry conditions in the western Mediterranean region (Baldi et al., 2004; Xoplaki et al.,

607 2003). These climatic conditions could also originate from the Indian summer monsoon and

608 its impact on subsidence over the Mediterranean Sea through the westward propagation of

609 Rossby waves (Marzin and Braconnot, 2009; Rodwell and Hoskins, 1996; Rodwell and

610 Hoskins, 2001). By considering the extreme northward position of the ITCZ and the strong

611 seasonality pattern (i.e., summer insolation maxima versus winter insolation minima) during

612 interglacial s.s., the summer conditions over the Mediterranean adding to the subsequent rapid

613 climate deterioration occurring in autumn/winter could have increased the air-sea temperature

614 contrast and, correspondingly, the necessary heat and moisture fluxes required for the

615 development and strengthening of cyclonic circulations over the northern Mediterranean 
616 borderlands (Kutzbach et al., 2014; Meijer and Tuenter, 2007; Trigo et al., 2002; Trigo et al., 617 1999; Tuenter et al., 2003). This allowed the autumn/winter rainy westerlies to reach the

618 Mediterranean area more frequently. This pattern could explain the intimate relationship 619 observed between the North African summer monsoon and the Mediterranean autumn/winter 620 rainfall during MIS 5e, while also giving insights into the mechanism for the transfer of 621 energy between the tropics and higher latitudes (Rohling et al., 2002).

622

\subsection{Mediterranean rainfall events and sapropel deposition}

624

The origin of sapropel deposits, and precisely the source(s) for freshwater, nutrients and continental organic matter, has long been debated (e.g., Rohling et al., 2015). The meltwater runoff from the Fennoscandian ice sheet into the Eastern Mediterranean by way of the Black and Aegean seas was first proposed (Ryan, 1972; Williams et al., 1978). Later, RossignolStrick et al. (1982) and Rossignol-Strick (1985) identified heavy Nile River summer floods due to increased monsoonal summer precipitation over Ethiopia as the main forcing for 631 sapropel deposition. The contribution from Macedonian, Greek and Turkish rivers, in addition 632 to that of the Nile, was then pointed out (Cramp et al., 1988; Rossignol-Strick, 1987; Shaw and Evans, 1984; Wijmstra et al., 1990). Although these studies only focused on the Late

634 Pleistocene and Sapropel S1, it has been widely accepted that precipitation over the northern 635 borderlands of the Eastern Mediterranean also played a significant role for sapropel 636 deposition (Rohling and Hilgen, 1991; Rossignol-Strick, 1987). This assumption was 637 ultimately supported through the 250-kyr isotopic record of cave speleothems from the Levant 638 that revealed that the periods for deposition of Sapropel S1 to S9 were characterized by 639 enhanced rainfall of Mediterranean origin in the eastern Mediterranean land and sea regions 640 (Bar-Matthews et al., 2003; Bar-Matthews et al., 2000). At the other side of the 
641 Mediterranean realm, a few studies revealed that increased precipitation over the Western

642 Mediterranean occurs simultaneously with the formation of Sapropel S1 (Ariztegui et al., 643 2000; Kotthoff et al., 2008; Magny et al., 2013; Zanchetta et al., 2007), Sapropel S4

644 (Regattieri et al., 2015), Sapropel S5 (Drysdale et al., 2005; Kallel et al., 2000), Sapropel S6

645 (Bard et al., 2002) and Sapropel S7 (Kallel et al., 2000), thus suggesting that increased rainfall

646 during sapropel deposition was not restricted to the Eastern Mediterranean. Although 647 compelling, each of these records were discontinuous in character. The correlation of the 547648 kyr GDEC-4-2 sequence for Golo River runoff with the long speleothem records from the 649 Levant (Bar-Matthews et al., 2003), as well as with the continental and marine (short) records 650 scattered in the central and eastern Mediterranean regions (Ariztegui et al., 2000; Bard et al., 651 2002; Cramp et al., 1988; Emeis et al., 2000; Göktürk et al., 2011; Kallel et al., 2000; 652 Kotthoff et al., 2008; Milner et al., 2012; Regattieri et al., 2015; Rossignol-Strick, 1987; Shaw 653 and Evans, 1984; Wijmstra et al., 1990; Zanchetta et al., 2007) confirms that increased 654 rainfall was widespread over the northern Mediterranean borderlands during sapropel 655 deposition.

656 Our evidence for enhanced rainfall activity along the northern Mediterranean borderlands 657 during warm intervals of interglacial periods provides an additional constraint on the role of 658 the mid-latitude storm tracks on the forcing leading to sapropel deposition. First by increasing 659 the flux of continental organic matter to the oceanic basin through river runoff, with possible 660 subsequent positive effects on the primary productivity and the marine organic matter flux to 661 the seafloor (e.g., Rohling and Hilgen, 1991). Second, by creating the necessary hydrological 662 changes leading to disruption in the basin's hydrological cycle and reduced intermediate and 663 deep water ventilation (Meijer and Tuenter, 2007). Indeed, it has been shown that the Nile 664 input was not the only factor affecting the freshwater balance of the Eastern Mediterranean 665 during sapropel events (Scrivner et al., 2004). Based on these considerations, we propose the 
following scenario for interglacials s.s.: precession-driven Northern Hemisphere insolation

667 maxima, through the northward shift of the ITCZ, led to heavy summer rainfall (June668 September; Janowiak, 1988) over Northern Africa and to subsequent summer-autumnal 669 (August-October; Conway and Hulme, 1993) Nile (and wadi-systems) floods into the Eastern 670 Mediterranean (Coulthard et al., 2013; Rohling et al., 2002; Rossignol-Strick, 1985). At 671 seasonal scale, warm and arid conditions prevailed in summer over southern Europe and the 672 Mediterranean until the rapid arrival of autumn/winter conditions due to the extreme seasonality (i.e., precession minima). The Mediterranean storm track intensified and rainfall was enhanced over the northern Mediterranean borderlands until the next spring and the rapid recovery of hot dry conditions over the Mediterranean. Thus, high flux of freshwater, nutrient 676 and continental organic matter entered the Mediterranean Sea from the Northern African margin and the northern Mediterranean borderlands in summer/autumn and autumn/winter, respectively. This indicates that on an annual scale, the rainfall over the northern Mediterranean Sea maintained the reduced sea-surface water salinities and the high-flux of 680 nutrient and organic matter in the Mediterranean Sea initially caused by the Nile (and wadi681 systems) floods, until the next spring. This pattern prevailed as the insolation/seasonality is 682 high and deeply affects, through its duration, the basin's hydrological cycle up to the 683 development of widespread bottom anoxic conditions. It is difficult to determine whether Nile 684 floods or rainfall over the northern Mediterranean borderlands is the dominant forcing of 685 changes in stratification and deep water formation (Bosmans et al., 2015). Meijer and Tuenter 686 (2007) have previously shown that the effects of increased rainfall over the northern 687 Mediterranean borderlands are possibly of equal or greater importance than that of increased 688 Nile discharge. A prerequisite for such an impact is that rainfall had an extra-Mediterranean 689 origin, since local rainfall (i.e., convective precipitation) cannot have affected the intermediate 690 and deep water ventilation significantly (Rohling et al., 2015). Such an origin is questioned by 
691 recent numerical modelling (Bosmans et al., 2015) but there is support from the North 692 Atlantic source of modern extreme-rainfall episodes over the northern Mediterranean 693 borderlands (e.g., Celle-Jeanton et al., 2004; Duffourg and Ducrocq, 2013; Reale et al., 2001), 694 from studies showing surface ocean dilution (Emeis et al., 2003; Kallel et al., 2000; Kallel et 695 al., 1997) and from changes in the sources of precipitation in the Western Mediterranean at 696 time of sapropel formation (e.g., Bard et al., 2002; Drysdale et al., 2004; Zanchetta et al., 697 2007).

698 


\section{CONCLUSION}

700

701 The 125 metres-long GDEC-4-2 borehole provides a continuous high-resolution paleoclimatic record on the East Corsica margin, northern Tyrrhenian Sea, over the last 547 kyr. Sedimentological, geochemical and micropaleotological analysis reveal a close coupling between river runoff and climate changes over the studied period, and during warm intervals of interglacial periods especially. The main results of our study are the following:

1. Warm intervals of interglacial periods and interglacials s.s. are characterised by high terrigenous flux and benthic foraminifera indicative of high organic matter input. This evidence points to high sediment discharges by East Corsica rivers in response to high precipitation levels;

2. Comparison of GDEC-4-2 proxy records for river discharge with pollen sequences and speleothems from the central and eastern Mediterranean reveals that the interglacial wet

714 conditions recorded off Corsica were regional in character. Considering the present-day

715 Mediterranean climate pattern and palynological evidence, our dataset likely records the activity of the autumn/winter Mediterranean storm track along the northern Mediterranean borderlands and its intensification during interglacials s.s.;

3. If the correlation between the rainfall activity over the northern Mediterranean borderlands and the interglacial warm intervals confirms the precessional component of the Mediterranean

721 climate, the GDEC-4-2 record is long enough to highlight the impact of eccentricity modulation of precession (and insolation) on the Mediterranean cyclogenesis; 
724 4. Our dataset reveals a correlation between the timing of maxima of the Mediterranean

725 autumn/winter storm track precipitation and that of the North African summer monsoon.

726 Millennial-scale examination of the penultimate interglacial s.s. (MIS 5e) suggests that

727 climate conditions over North Africa (and possibly India) and the Mediterranean in summer

728 could force the cyclogenesis activity on the northern Mediterranean borderlands during the

729 successive autumn/winter. This highlights a close coupling between low- and mid-latitude

730 hydrological changes;

731

732 5. Finally, our findings suggest that during warm intervals of interglacial periods the reduced

733 sea-surface water salinities, together with the high flux of nutrient and organic matter,

734 produced by the monsoonal (i.e., summer/autumn) Nile (and wadi-systems) floods, were

735 maintained throughout the winter by the Mediterranean rainfall. This identifies rainfall over

736 the northern Mediterranean borderlands, in addition to the river runoff from the Libyan-

737 Egyptian sector of North Africa, as a possible forcing on sapropel deposition.

738 


\section{ACKNOWLEDGMENTS}

740

741 The authors are very grateful to A. Roubi, M. Rovere, C. Marin, M. Montferrand, L. Blanchet

742 (IFREMER) and J. Duprat for their technical support; E. Michel, F. Dewilde, G. Isguder

743 (LSCE) for their expert analytical work about stable isotopes measurements; D. Hodell and

744 P.C. Tzedakis that kindly provided data from the Iberian margin and Tenaghi Philippon,

745 respectively; T. Caley, Y. Dixit, N. Freslon, T. Konijnendijk, M. Rogerson, M.F. Sánchez

746 Goñi and M. Ziegler for invaluable discussions at various stages of this work; and three

747 anonymous reviewers who provide helpful review of the manuscript. The authors also thank

748 the crew and scientific team (G. Calvès, G. Dan-Unterseh, L. Droz, I. Jégou, G. Lericolais, E.

749 Marchès, T. Marsset) of the GOLODRILL cruise (R/V 'Bavenit' - FUGRO) for the recovery

750 of the GDEC-4-2 borehole. This study has been realised in the frame of the "GOLO

751 PROGRAM", a research consortium between IFREMER, TOTAL, EXXONMOBIL and

752 FUGRO. 


\section{TABLE CAPTION}

755

756 Table 1. Chronological framework for GDEC-4-2. The ages of isotope events from the

757 North-GRIP ice core (0-60 ka interval, GICC05 chronology; Rasmussen et al., 2006;

758 Svensson et al., 2008) and the synthetic Greenland (GL $\mathrm{GL}_{\mathrm{T}} \mathrm{Syn}, 60-550 \mathrm{ka}$ interval) record of

759 Barker et al. (2011) were used to calibrate isotope events in the core. GI is Greenland

760 Interstadial; MIS is Marine Isotope Stage; $\mathrm{T}$ is Termination. Scheme of marine isotope

761 substages according to Railsback et al. (2015). Radiocarbon ages (i.e., CALIB 7 Age) refer to

762 Table 2. Ages marked by an asterik (chronological inversion) are not included in the age

763 model.

764

765 Table 2. Radiocarbon ages for GDEC-4-2. The age dates were corrected for a marine

766 reservoir effect of 400 years, except for those from the period 15-17 ka (marked by an

767 asterisk) for which a correction of 800 years was applied (cf. Siani et al., 2001). Radiocarbon

768 ages were calibrated to calendar years using CALIB 7.0.0 and the IntCal13 calibration curve

769 (Reimer et al., 2013).

770

771

772 


\section{FIGURE CAPTION}

Figure 1. Location of the main sites mentioned in the text, including the GDEC-4-2 borehole (red circle). The blue and green circles (with associated colored names) indicate the marine and continental (i.e., speleothems, pollen sequences) records, respectively. See the main text

778 for references. The modern (approximate) position of the Azores High and of the ITCZ (red bands) is shown. The dashed red line over North Africa show the maximum northward displacement of the ITCZ over the last million years (e.g., Tuenter et al., 2003). Course of the Central Saharan rivers according to Coulthard et al. (2013). The orange arrow shows the Mediterranean storm track.

Figure 2. Schematic dip section across the East Corsica margin, from the Golo River mouth to the Golo basin, illustrating the stacking of the last five sedimentary sequences bounded by major discontinuities on the shelf and attributed to 100 kyr-glacio-eustatic cyles. The stratigraphic scheme attests the presence of transgressive and highstand (i.e., interglacial) accumulations, imprinted by stacked continuous and regional seismic reflections representing thick interglacial sedimentary intervals (ca. 10-15m). Note that the borehole GDEC-4-2 is located between the North Golo canyon and the South Golo canyon. This makes GDEC-4-2 well suited for continuously recording sediment input variability from the Golo River throughout the last climate cycles.

794 Figure 3. (A) Greenland synthetic $\delta^{18} \mathrm{O}$ record (GLT-syn ; Barker et al., 2011); (B) $\delta^{18} \mathrm{O}$ of $G$. bulloides from the combined record of core MD01-2444 and MD01-2443, Iberian margin (Hodell et al., 2013); (C) Composite $\delta^{18} \mathrm{O}$ of $G$. bulloides, G. ruber (white) and $N$. pachyderma (dextral) of the GDEC-4-2 borehole (green tones). The chronology for GDEC-4- 
7982 was constructed by aligning this planktonic $\delta^{18} \mathrm{O}$ record to the synthetic Greenland $\left(\mathrm{GL}_{\mathrm{T}}-\right.$ 799 syn) record of Barker et al. (2011). The triangles at the bottom part of the figure indicate the 800 tie points (see Table 1 for details). The yellow (continuous) and purple (dashed) lines 801 correspond to the $\delta^{18} \mathrm{O}$ of $G$. bulloides at site MD01-2472, East Corsica margin (Toucanne et 802 al., 2012) and at site ODP 975, West Balearic Basin (Pierre et al., 1999), respectively. The $\delta^{18} \mathrm{O}$ at site ODP 975 is offset by $-1 \%$ to facilitate the comparison with the GDEC-4-2 and MD01-2472 records; (D) XRF $\mathrm{Ca} / \mathrm{Ti}$ (log scale; blue line) and weight percent calcium 805 carbonate (wgt. $\% \mathrm{CaCO}_{3}$; red line) of the GDEC-4-2 borehole. The black line corresponds to 806 the wgt. $\% \mathrm{CaCO}_{3}(-5 \%$ for comparison with the GDEC-4-2 dataset) for core LC06, Balearic Abyssal Plain (Hoogakker et al., 2004). Note the opposite evolution of the wgt. $\% \mathrm{CaCO}_{3}$ during interglacial warm intervals (i.e, MIS 5a, 5c, 5e) at sites GDEC-4-2 (\% $\mathrm{CaCO}_{3}$ lows) and $\mathrm{LC} 06\left(\% \mathrm{CaCO}_{3}\right.$ highs $)$. The red arrows highlight the unexpected low levels for carbonate content (i.e., ' $\mathrm{CaCO}_{3}$ paradox', see the main text for details); (E) Composite $\delta^{18} \mathrm{O}$ of $C$. pachyderma, C. kullenbergi and $C$. wuellerstorfi of the GDEC-4-2 borehole. Light grey 812 vertical bands indicate interglacial conditions s.l., while dark bands indicate interglacial warm 813 intervals and the interglacial s.s. (i.e., MIS 1, MIS 5e, MIS 7c, 7e, MIS 9, MIS11 and MIS 814 13c). Terminations (T.) I to VI according to Barker et al. (2011). Scheme of marine isotope substages according to Railsback et al. (2015).

817 Figure 4. Weight percent calcium carbonate (weight $\% \mathrm{CaCO}_{3}$ ) versus $\mathrm{XRF} \mathrm{Ca} / \mathrm{Ti}(\log$ scale) $818 \quad(\mathrm{n}=1412, \mathrm{r}=0.91 / \mathrm{p}<0.01)$

Figure 5. (A) XRF Ca/Ti (log scale) of the GDEC-4-2 borehole (blue line) and of the combined record of core MD01-2444 and MD01-2443 (orange line), Iberian margin (Hodell et al., 2013). The red arrows highlight the $\% \mathrm{CaCO}_{3}$ lows identified in Figure 3 (i.e., ' $\mathrm{CaCO}_{3}$ 
823

824

825

826

827

828

829

830

831

832

833

834

835

836

837

838

839

840

841

842

paradox', see the main text for details); (B) Terrigenous flux (i.e., mass accumulation rates) at site GDEC-4-2 (grey line). The blue line depicts terrigenous flux normalised to the changing distance between the Golo river mouth and the GDEC-4-2 borehole with regard to sea-level changes (see Fig. 5e). The red arrows highlight unexpected high terrigenous flux during interglacials s.s. (see the main text for details); (C) XRF Ti/Ca (log scale) of the GDEC-4-2

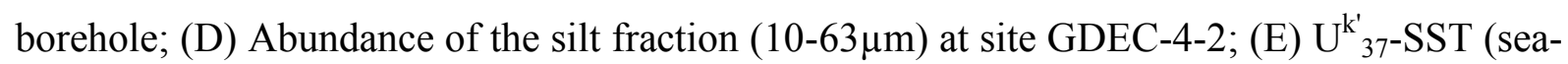
surface temperature) of the combined record of core MD01-2444 and MD01-2443 (orange line), Iberian margin (Martrat et al., 2007). The blue shaded interval depicts the 95\% probability interval for the probability maximum of the Red Sea relative sea-level (RSL) dataset (core KL09; Grant et al., 2012; Grant et al., 2014); (F) Composite $\delta^{18} \mathrm{O}$ of $G$. bulloides, G. ruber (white) and N. pachyderma (dextral) of the GDEC-4-2 borehole (green tones). Light grey bands indicate interglacial conditions s.l., while dark bands indicate interglacial warm intervals and the interglacial s.s. (i.e., MIS 1, MIS 5e, MIS 7c, 7e, MIS 9, MIS11 and MIS 13c). Terminations (T.) I to VI according to Barker et al. (2011). Scheme of marine isotope substages according to Railsback et al. (2015).

Figure 6. (A) Composite $\delta^{18} \mathrm{O}$ of G. bulloides, G. ruber (white) and N. pachyderma (dextral) of the GDEC-4-2 borehole (green tones); (B) Abundance of the benthic foraminifera eutrophic group; (C) Abundance of the deep-infaunal foraminifera (red line) and eccentricity of the Earth's orbit (dashed grey line; Laskar et al., 2004). The interglacials (s.s.) terrigenous flux at site GDEC-4-2 are also shown (blue diamonds). These fluxes can be compared since similar sea-level highstand conditions prevailed during these intervals; (D) Composite $\delta^{13} \mathrm{C}$ of C. pachyderma $\left(\delta^{13} \mathrm{C}_{C p}\right)$, C. kullenbergi $\left(\delta^{13} \mathrm{C}_{C k}\right)$ and $C$. wuellerstorfi $\left(\delta^{13} \mathrm{C}_{C w}\right)$ of the GDEC4-2 borehole. Depletions of both $\delta^{13} \mathrm{C}_{C p}$ and $\delta^{13} \mathrm{C}_{C k}$ signals below $0.3 \%$, and of the $\delta^{13} \mathrm{C}_{C w}$ signal below $0.9 \%$ are likely related to episodes of enhanced organic-matter mineralization 
within the sediment. These events are represented by vertical blue bands; (E) June insolation

849 for $65^{\circ} \mathrm{N}$ (black line) and precession (dashed grey line) (Laskar et al., 2004). Light grey bands 850 indicate interglacial conditions s.l., while dark bands indicate interglacial warm intervals and 851 the interglacial s.s. (i.e., MIS 1, MIS 5e, MIS 7c, 7e, MIS 9, MIS11 and MIS 13c). 852 Terminations (T.) I to VI according to Barker et al. (2011). Chronology for sapropel (S) layers 853 (speleothem age-scale) according to Ziegler et al. (2010) until Sapropel S9 and Konijnendijk 854 et al. (2014) thereafter. Scheme of marine isotope substages according to Railsback et al. 855 (2015).

857 Figure 7. (A) $\delta^{18} \mathrm{O}$ record of the Soreq (Central Israel, black line; Bar-Matthews et al., 2003), 858 Peqiin (Northern Israel, grey line; Bar-Matthews et al., 2003), Antro del Corchia (Central 859 Italy, orange line; Drysdale et al., 2005; Zanchetta et al., 2007), Tana Che Urla (Central Italy, 860 purple line; Regattieri et al., 2014) and Argentarola (Tyrrhenian coast of Italy, green line; 861 Bard et al., 2002) speleothems. The $\delta^{18} \mathrm{O}$ record of the Sulmona basin (Central Italy, pink line; 862 Regattieri et al., 2015) is also shown; (B) Abundance of the benthic foraminifera deep863 infaunal group (red line) and eccentricity of the Earth's orbit (dashed grey line; Laskar et al., 864 2004). The interglacials (s.s.) terrigenous flux at site GDEC-4-2 are also shown (blue 865 diamonds). These fluxes can be compared since similar sea-level highstand conditions 866 prevailed during these intervals; (C) XRF Ca/Ti (log scale) of the GDEC-4-2 borehole; (D) 867 XRF Ba/Al (log scale) from ODP 968 (Southern Cyprus; Ziegler et al., 2010). High Ba/Al 868 ratios are very characteristic for sapropel layers. Chronology for sapropel layers (speleothem 869 age-scale) according to Ziegler et al. (2010); (E) $\delta^{18}$ O record of the Sanbao-Hulu caves (Wang 870 et al., 2008); (F) Tenaghi Philippon temperate tree pollen percentages (Tzedakis et al., 2006); 871 (G) June insolation for $65^{\circ} \mathrm{N}$ (black line) and precession (dashed grey line) (Laskar et al., 872 2004). Seasonality at $65^{\circ} \mathrm{N}$ (green line) is shown through the difference JJA (June, July, 
873 August) - DJF (December, January, February). Vertical blue bands indicate the timing for 874 sapropel deposition (Ziegler et al., 2010). Terminations (T.) I to III according to Barker et al. 875 (2011). Scheme of marine isotope substages according to Railsback et al. (2015).

876

877 Figure 8. (A) June insolation (blue line) and seasonality (JJA-DJF, purple line) for $45^{\circ} \mathrm{N}$ 878 (Laskar et al., 2004); (B) Alboran Sea SST, ODP 976 and ODP 977 (Martrat et al., 2014); (C) 879 Pollen percentage data for sclerophyllous Mediterranean at Tenaghi Philippon (Milner et al., 880 2012); (D) XRF Ca/Ti (log scale; continuous line) and abundance of the silt fraction (dashed 881 line) at site GDEC-4-2; (E, F, G) $\delta^{18} \mathrm{O}$ of $G$. ruber (white) in core KS205 (Ionian Sea), ODP 882971 (Levantine Sea) and ODP 967 (Southern Cyprus), all plotted versus the ODP 971883 equivalent depth scale (see Rohling et al., 2002 for details). Conversion on the speleothem 884 age-scale is based on the alignment of the $\delta^{18} \mathrm{O}$ of $G$. ruber in ODP 967 (i.e., enhanced Nile 885 outflow at time of Sapropel S5; Rohling et al., 2002) on the Ba/Al ratio (Sapropel S5 layer, 886 see Figure 8h) of Ziegler et al. (2010) in ODP 968 (located ca. $30 \mathrm{~km}$ north); (H) XRF Ba/Al 887 (log scale) from ODP 968 (Southern Cyprus; Ziegler et al., 2010); (I) Paleorainfall $\delta^{18} \mathrm{O}$ 888 values at Soreq Cave (Central Israel; Bar-Matthews et al., 2003); (J) Continental climatic 889 episodes (Ducassou et al., 2009 and references therein). Chronology (speleothem age-scale) 890 for Sapropel S5 according to Ziegler et al. (2010). 
893

894

895

896

897

898

899

900

901

902

903

904

905

906

907

908

909

910

911

912

913

914

915

916

917

918

919

920

921

922

923

924

925

926

927

928

929

930

931

932

933

934

935

936

937

938

Abels, H.A., Abdul Aziz, H., Calvo, J.P. and Tuenter, E., 2009. Shallow lacustrine carbonate microfacies document orbitally paced lake-level history in the Miocene Teruel Basin (North-East Spain). Sedimentology, 56(2): 399-419.

Abu-Zied, R.H., Rohling, E.J., Jorissen, F.J., Fontanier, C., Casford, J.S.L. and Cooke, S., 2008. Benthic foraminiferal response to changes in bottom-water oxygenation and organic carbon flux in the eastern Mediterranean during LGM to Recent times. Marine Micropaleontology, 67: 46-68.

Allen, J.R.M. et al., 1999. Rapid environmental changes in southern Europe during the last glacial period. Nature, 400: 740-743.

Ariztegui, D. et al., 2000. Palaeoclimate and the formation of sapropel S1: inferences from Late Quaternary lacustrine and marine sequences in the central Mediterranean region. Palaeogeography, Palaeoclimatology, Palaeoecology, 158(3-4): 215-240.

Arz, H.W., Lamy, F., Pätzold, J., Müller, P.J. and Prins, M.A., 2003. Mediterranean Moisture Source for an Early-Holocene Humid Period in the Northern Red Sea. Science, 300: $118-121$.

Baldi, M., Meneguzzo, F., Dalu, G.A., Maracchi, G., Pasqui, M., Capecchi, V., Crisci, A. and Piani, F., 2004. Guinea GULF SST and Mediterranean summer climate: analysis of the interannual variability. Bulletin of the American Meteorological Society: 41674187.

Balsam, W.L. and McCoy, F.W., 1987. Atlantic sediments: glacial/interglacial comparisons. Paleoceanography, 2(5): 531-542.

Bar-Matthews, M., Ayalon, A., Gilmour, M., Matthews, A. and Hawkesworth, C.J., 2003. Sea-land oxygen isotopic relationships from planktonic foraminifera and speleothems in the Eastern Mediterranean region and their implication for paleorainfall during interglacial intervals. Geochimica et Cosmochimica Acta, 67(17): 3181-3199.

Bar-Matthews, M., Ayalon, A. and Kaufman, A., 2000. Timing and hydrological conditions of Sapropel events in the Eastern Mediterranean, as evident from speleothems, Soreq cave, Israel. Chemical Geology, 169(1-2): 145-156.

Bard, E., Delaygue, G., Rostek, F., Antonioli, F., Silenzi, S. and Schrag, D.P., 2002. Hydrological conditions over the western Mediterranean basin during the deposition of the cold Sapropel 6 (ca. 175 kyr BP). Earth and Planetary Science Letters, 202: 481-494.

Barker, S., Knorr, G., Edwards, R.L., Parrenin, F., Putnam, A.E., Skinner, L.C., Wolff, E. and Ziegler, M., 2011. 800,000 years of abrupt climate variability. Science, 334(6054): 347-351.

Berger, A., 1978. Long-term variations of daily insolation and Quaternary Climatic Changes. Journal of Atmospheric Science, 35(12): 2362-2367.

Blum, M.D. and Törnqvist, T.E., 2000. Fluvial responses to climate and sea-level change: A review and look forward. Sedimentology, 47: 2-48.

Bonneau, L., Jorry, S.J., Toucanne, S., Silva Jacinto, R. and Emmanuel, L., 2014. Millenialscale response of a Western Mediterranean river to Late Quaternary climate changes: a view from the deep sea. The Journal of Geology, 122(6): 687-703.

Bosmans, J.H.C., Drijfhout, S.S., Tuenter, E., Hilgen, F.J., Lourens, L.J. and Rohling, E.J., 2015. Precession and obliquity forcing of the freshwater budget over the Mediterranean. Quaternary Science Reviews, 123: 16-30. 
Brauer, A., Allen, J.R.M., Mingram, J., Dulski, P., Wulf, S. and Huntley, B., 2007. Evidence for last interglacial chronology and environmental change from Southern Europe. Proceedings of the National Academy of Sciences, 104(2): 450-455.

Cacho, I., Grimalt, J.O., Pelejero, C., Canals, M.l., Sierro, F.J., Flores, J.A. and Shackleton, N., 1999. Dansgaard-Oeschger and Heinrich events imprints in Alboran Sea paleotemperatures. Paleoceanography, 14(6): 698-705.

Calvès, G. et al., 2013. Inferring denudation and climatic variations from the sediment record; an example of the last glacial cycle record of the Golo basin and watershed, East Corsica, western Mediterranean Sea. Basin Research, 25(2): 197-218.

Casford, J.S.L., Rohling, E.J., Abu-Zied, R.H., Fontanier, C., Jorissen, F.J., Leng, M.J., Schmiedl, G. and Thomson, J., 2003. A dynamic concept for eastern Mediterranean circulation and oxygenation during sapropel formation. Palaeogeography, Palaeoclimatology, Palaeoecology, 190: 103-119.

Celle-Jeanton, H., Travi, Y. and Blavoux, B., 2004. Isotopic typology of the precipitation in the Western Mediterranean region at three different time scales. Geophysical Research Letters, 28: 1215-1218.

Conway, D. and Hulme, M., 1993. Recent fluctuations in precipitation and runoff over the Nile sub-basins and their impact on main Nile discharge. Climatic change, 25(2): 127151.

Coulthard, T.J., Ramirez, J.A., Barton, N., Rogerson, M. and Brücher, T., 2013. Were Rivers Flowing across the Sahara During the Last Interglacial? Implications for Human Migration through Africa. PLoS One, 8(9): doi:10.1371/journal.pone.0074834.

Cramp, A., Collins, M. and West, R., 1988. Late Pleistocene Holocene sedimentation in the NW Aegean Sea: a palaeo- climatic palaeoceanographic reconstruction. Palaeogeography, Palaeoclimatology, Palaeoecology, 68: 61-77.

Cremer, M., Grousset, F., Faugeres, J.C., Duprat, J. and Gonthier, E., 1992. Sediment flux patterns in the northeastern Atlantic: variability since the last interglacial. Marine Geology, 104(1-4): 31-53.

Desprat, S., Sanchez Goni, M.F., Turon, J.L., Duprat, J., Malaize, B. and Peypouquet, J.P., 2006. Climatic variability of Marine Isotope Stage 7: direct land-sea-ice correlation from a multiproxy analysis of a north-western Iberian margin deep-sea core. Quaternary Science Reviews, 25: 1010-1026.

Drake, N.A., Blench, R.M., Armitage, S.J., Bristow, C.S. and White, K.H., 2011. Ancient watercourses and biogeography of the Sahara explain the peopling of the desert. Proceedings of the National Academy of Sciences, 108(2): 458-462.

Drysdale, R.N., Zanchetta, G., Hellstrom, J.C., Fallick, A.E. and Zhao, J.X., 2005. Stalagmite evidence for the onset of the Last Interglacial in southern Europe at $129 \pm 1 \mathrm{ka}$. Geophysical Research Letters, 32(24): DOI: 10.1029/2005GL024658.

Drysdale, R.N., Zanchetta, G., Hellstrom, J.C., Fallick, A.E., Zhao, J.X., Isola, I. and Bruschi, G., 2004. Palaeoclimatic implications of the growth history and stable isotope $\left(\delta^{18} \mathrm{O}\right.$ and $\delta^{13} \mathrm{C}$ ) geochemistry of a Middle to Late Pleistocene stalagmite from centralwestern Italy. Earth and Planetary Science Letters, 227(3-4): 215-229.

Ducassou, E., Migeon, S., Mulder, T., Murat, A., Capotondi, L., Bernasconi, S.M. and Mascle, J., 2009. Evolution of the Nile Deep-Sea turbidite system during the Late Quaternary: influence of climate change on fan sedimentation. Sedimentology, 56: 2061-2090.

Duffourg, F. and Ducrocq, V., 2013. Assessment of the water supply to Mediterranean heavy precipitation: a method based on finely designed water budgets. Atmospheric Science Letters, 14(3): 133-138. 
Duplessy, J.C., 1978. Isotopes Studies, J. Gribbin (Ed.), Climatic Change, Cambridge Univ. Press, London/New York (1978), pp. 46-67.

Eberwein, A. and Mackensen, A., 2006. Regional primary productivity differences off Morocco (NW-Africa) recorded by modern benthic foraminifera and their stable carbon isotopic composition. Deep Sea Research Part I: Oceanographic Research Papers, 53: 1379-1405.

Emeis, K.C. et al., 2003. Eastern Mediterranean surface water temperatures and $\delta^{18} \mathrm{O}$ composition during deposition of sapropels in the late Quaternary. Paleoceanography, 18(1): 1005, doi:10.1029/2000PA000617.

Fletcher, W.J. and Sánchez Goñi, M.F., 2008. Orbital- and sub-orbital-scale climate impacts on vegetation of the western Mediterranean basin over the last 48,000 yr. Quaternary Research, 70: 451-464.

Fontanier, C., Biscara, L., Mamo, B. and Delord, E., 2014. Deep-sea foraminifera in an area around the Cassidaigne Canyon (NW Mediterranean) affected by bauxite discharge. Marine Biodiversity, 1-12, DOI 10.1007/s12526-014-0281-9

Fontanier, C., Jorissen, F.J., Anschutz, P. and Chaillou, G., 2006a. Seasonal variability of benthic foraminiferal faunas at $1000 \mathrm{~m}$ depth in the Bay of Biscay. Journal of Foraminiferal Research, 36: 61-76.

Fontanier, C., Jorissen, F.J., Chaillou, G., Anschutz, P., Grémare, A. and Griveaud, C., 2005. Live foraminiferal faunas from a $2800 \mathrm{~m}$ deep lower canyon station from the Bay of Biscay: Faunal response to focusing of refractory organic matter. Deep Sea Research Part I: Oceanographic Research Papers, 52: 1189-1227.

Fontanier, C., Mackensen, A., Jorissen, F.J., Anschutz, P., Licari, L. and Griveaud, C., 2006b. Stable oxygen and carbon isotopes of live benthic foraminifera from the Bay of Biscay: Microhabitat impact and seasonal variability. Marine Micropaleontology, 58(3): 159-183.

Forzoni, A., Storms, J.E.A., Reimann, T., Moreau, J. and Jouet, G., 2015. Non-linear response of the Golo River system, Corsica, France, to Late Quaternary climatic and sea level variations. Quaternary Science Reviews, 121: 11-27.

Gasse, F. et al., 2014. Hydroclimatic changes in northern Levant over the past 400,000 years. Quaternary Science Reviews, 111: 1-8.

Goineau, A. et al., 2012. Temporal variability of live (stained) benthic foraminiferal faunas in a river-dominated shelf-faunal response to rapid changes of the river influence (Rhône prodelta, NW Mediterranean). Biogeosciences, 9: 1367-1388.

Göktürk, O.M., Fleitmann, D., Badertscher, S., Cheng, H., Edwards, R.L., Leuenberger, M., Fankhauser, A., Tüysüz, O. and Kramers, J., 2011. Climate on the southern Black Sea coast during the Holocene: implications from the Sofular Cave record. Quaternary Science Reviews.

Grant, K.M., Rohling, E.J., Bar Matthews, M., Ayalon, A., Medina Elizalde, M., Bronk Ramsey, C., Satow, C. and Roberts, A.P., 2012. Rapid coupling between ice volume and polar temperature over the past 150,000 years. Nature, 491: 744-747.

Grant, K.M. et al., 2014. Sea-level variability over five glacial cycles. Nature Communications, 5: 5076.

Griveaud, C., 2007. Influence des conditions écologiques sur la composition isotopique $\left(\delta^{13} \mathrm{C}\right.$, $\left.\delta^{18} \mathrm{O}\right) \mathrm{du}$ test de foraminifères benthiques actuels. Unpublished $\mathrm{PhD}$ thesis, Université d'Angers, 326 pp. .

Helmke, J.P. and Bauch, H.A., 2001. Glacial-interglacial relationship between carbonate components and sediment reflectance in the North Atlantic. Geo-Marine Letters, 21(1): 16-22. 
Hilgen, F.J., 1991. Astronomical calibration of Gauss to Matuyama sapropels in the Mediterranean and implication for the geomagnetic polarity time scale. Earth and Planetary Science Letters, 104: 226-244.

Hodell, D.A., Crowhurst, S., Skinner, L.C., Tzedakis, P.C., Margari, V., Channell, J.E.T., Kamenov, G., Maclachlan, S. and Rothwell, R.G., 2013. Response of Iberian Margin sediments to orbital and suborbital forcing over the past $420 \mathrm{ka}$. Paleoceanography, 28: 185-199, doi:10.1002/paleo.20017.

Hoogakker, B.A.A., Rothwell, R.G., Rohling, E.J., Paterne, M., Stow, D.A.V., Herrle, J.O. and Clayton, T., 2004. Variations in terrigenous dilution in western Mediterraean Sea pelagic sediments in response to climate change during the last glacial cycle. Marine Geology, 211: 21-43.

Janowiak, J.E., 1988. An investigation of interannual rainfall variability in Africa. Journal of Climate, 1(3): 240-255.

Jo, K.N., Woo, K.S., Yi, S., Yang, D.Y., Lim, H.S., Wang, Y., Chen, G. and Edwards, R.L., 2014. Mid-latitude interhemispheric hydrologic seesaw over the past 550,000 years. Nature, 508: 378-382.

Kallel, N., Duplessy, J.C., Labeyrie, L., Fontugne, M., Paterne, M. and Montacer, M., 2000. Mediterranean pluvial periods and sapropel formation over the last 200000 years. Palaeogeography, Palaeoclimatology, Palaeoecology, 157: 45-58.

Kallel, N., Paterne, M., Duplessy, J.C., Vergnaud-Grazzini, C., Pujol, C., Labeyrie, L., Arnold, M., Fontugne, M. and Pierre, C., 1997. Enhanced rainfall in the mediterranean region during the last sapropel event. Oceanologica Acta, 20(5): 697-712.

Konijnendijk, T.Y.M., Ziegler, M. and Lourens, L.J., 2014. Chronological constraints on Pleistocene sapropel depositions from high-resolution geochemical records of ODP Sites 967 and 968. Newsletters on Stratigraphy, 47(3): 263-282.

Kotthoff, U., Pross, J., Müller, U.C., Peyron, O., Schmiedl, G., Schulz, H. and Bordon, A., 2008. Climate dynamics in the borderlands of the Aegean Sea during formation of sapropel S1 deduced from a marine pollen record. Quaternary Science Reviews, 27(7): 832-845.

Kutzbach, J.E., Chen, G., Cheng, H., Edwards, R.L. and Liu, Z., 2014. Potential role of winter rainfall in explaining increased moisture in the Mediterranean and Middle East during periods of maximum orbitally-forced insolation seasonality. Climate Dynamics, 42(34): 1079-1095.

Larrasoana, J.C., Roberts, A.P., Rohling, E.J., Winklhofer, M. and Wehausen, R., 2003. Three million years of monsoon variability over the northern Sahara. Climate Dynamics, 21: 689-698, DOI 10.1007/s00382-003-0355-z.

Laskar, J., Robutel, P., Joutel, F., Gastineau, M., Correia, A.C.M. and Levrard, B., 2004. A long-term numerical solution for the insolation quantities of the Earth. Astronomy and Astrophysics, 428(1): 261-285.

Licari, L.N. and Mackensen, A., 2005. Benthic foraminifera off West Africa (11N to 321S): Do live assemblages from the topmost sediment reliably record environmental variability? Marine Micropaleontology, 55: 205-233.

Lisiecki, L.E. and Raymo, M.E., 2005. A Pliocene-Pleistocene stack of 57 globally distributed benthic $\delta^{18}$ O records. Paleoceanography, 20, PA1003, doi:10.1029/2004PA001071.

Lourens, L.J., Hilgen, F.J., Gudjonsson, L. and Zachariasse, W.J., 1992. Late Pliocene to early Pleistocene astronomically forced sea surface productivity and temperature variations in the Mediterranean. Marine Micropaleontology, 19: 49-78.

Magny, M. et al., 2013. North-south palaeohydrological contrasts in the central Mediterranean during the Holocene: tentative synthesis and working hypotheses. Climate of the Past, 9: 2043-2071, doi: 10.5194/cp-9-2043-2013. 
Margari, V., Skinner, L.C., Hodell, D.A., Martrat, B., Toucanne, S., Grimalt, J.O., Gibbard, P.L., Lunkka, J.P. and Tzedakis, C., 2014. Land-ocean changes on orbital and millenial time scales and the penultimate glaciation. Geology, 42(3): 183-186.

Martrat, B. et al., 2004. Abrupt temperature changes in the Western Mediterranean over the past 250,000 years. Science, 306(5702): 1762-1765.

Martrat, B., Grimalt, J.O., Shackleton, N.J., De Abreu, L., Hutterli, M.A. and Stocker, T.F., 2007. Four climate cycles of recurring deep and surface water destabilizations on the Iberian margin. Science, 317(5837): 502-507.

Martrat, B., Jimenez-Amat, P., Zahn, R. and Grimalt, J.O., 2014. Similarities and dissimilarities between the last two deglaciations and interglaciations in the North Atlantic region. Quaternary Science Reviews, 99: 122-134.

Meijer, P.T. and Tuenter, E., 2007. The effect of precession-induced changes in the Mediterranean freshwater budget on circulation at shallow and intermediate depth. Journal of Marine Systems, 68: 349-365.

Milner, A.M., Collier, R.E.L., Roucoux, K.H., Müller, U.C., Pross, J., Kalaitzidis, S., Christanis, K. and Tzedakis, P.C., 2012. Enhanced seasonality of precipitation in the Mediterranean during the early part of the Last Interglacial. Geology, 40: 919-922.

Murray, J.W., 2006. Ecology and application of benthic foraminifera, Cambridge University Press, Cambridge, UK (2006) 426 pp.

Osborne, A.H., Vance, D., Rohling, E.J., Barton, N., Rogerson, M. and Fello, N., 2008. A humid corridor across the Sahara for the migration of early modern humans out of Africa 120,000 years ago. Proceedings of the National Academy of Sciences, 105(43): 16444-16447.

Peyron, O., Goring, S., Dormoy, I., Kotthoff, U., Pross, J., de Beaulieu, J.L., DrescherSchneider, R. and Magny, M., 2011. Holocene seasonality changes in the central Mediterranean region reconstructed from the pollen sequences of Lake Accesa (Italy) and Tenaghi Philippon (Greece). The Holocene, 21: 131-146.

Pierre, C., 1999. The oxygen and carbon isotope distribution in the Mediterranean water masses. Marine Geology, 153(1-4): 41-45.

Pierre, C., Belanger, P., Saliège, J.F., Urrutiaguer, M.J. and Murat, A., 1999. Paleoceanography of the western Mediterranean during the Pleistocene: oxygen and carbon isotope records at Site 975. In: Zahn, R., Comas, M.C., Klaus, A. (Eds.), Proceedings of the Ocean Drilling Program, pp. 481.

Piva, A., Asioli, A., Andersen, N., Grimalt, J.O., Schneider, R. and Trincardi, F., 2008. Climatic cycles as expressed in sediments of the PROMESS1 borehole PRAD1-2, central Adriatic, for the last 370 kyr: 2. Paleoenvironmental evolution. Geochemistry, Geophysics, Geosystems, 9(3): Q03R02, doi:10.1029/2007GC001785.

Railsback, L.B., Gibbard, P.L., Head, M.J., Voarintsoa, N.R.G. and Toucanne, S., 2015. An optimized scheme of lettered marine isotope substages for the last 1.0 million years, and the climatostratigraphic nature of isotope stages and substages. Quaternary Science Reviews, 111(1): 94-106.

Rasmussen, S.O. et al., 2006. A new Greenland ice core chronology for the last glacial termination. Journal of Geophysical Research, 111, D06102, doi:10.1029/2005JD006079.

Reale, O., Feudale, L. and Turato, B., 2001. Evaporative moisture sources during a sequence of floods in the Mediterranean region. Geophysical Research Letters, 28(10): 20852088.

Regattieri, E., Giaccio, B., Zanchetta, G., Drysdale, R.N., Galli, P., Nomade, S., Peronace, E. and Wulf, S., 2015. Hydrological variability over the Apennines during the Early Last 
Glacial precession minimum, as revealed by a stable isotope record from Sulmona basin, Central Italy. Journal of Quaternary Science, 30(1): 19-31.

Regattieri, E., Zanchetta, G., Drysdale, R.N., Isola, I., Hellstrom, J.C. and Roncioni, A., 2014. A continuous stable isotope record from the penultimate glacial maximum to the Last Interglacial (159-121 ka) from Tana Che Urla Cave (Apuan Alps, central Italy). Quaternary Research, 82(2): 450-461.

Reimer, P.J. et al., 2013. Intcal13 and Marine13 radiocarbon age calibration curves 0-50,000 years cal BP. Radiocarbon, 55(4): 1869-1887.

Revel, M. et al., 2010. 100,000 Years of African monsoon variability recorded in sediments of the Nile margin. Quaternary Science Reviews, 29(11-12): 1342-1362.

Richter, T.O., Van Der Gaast, S., Koster, B., Vaars, A., Gieles, R., De Stigter, H.C., De Haas, H. and Van Weering, T.C.E., 2006. The Avaatech XRF Core Scanner: technical description and applications to NE Atlantic sediments. In: R.G. Rothwell (Editor), New Techniques in Sediment Core Analysis. Geological Society, Special Publications, pp. 39-50.

Roberts, D.H., Chiverrell, R.C., Innes, J.B., Horton, B.P., Brooks, A.J., Thomas, G.S.P., Turner, S. and Gonzalez, S., 2006. Holocene sea levels, Last Glacial Maximum glaciomarine environments and geophysical models in the northern Irish Sea Basin, UK. Marine Geology, 231(1-4): 113-128.

Rohling, E.J., 1994. Review and new aspects concerning the formation of Mediterranean sapropels. Marine Geology, 122: 1-28.

Rohling, E.J. et al., 2002. African monsoon variability during the previous interglacial maximum. Earth and Planetary Science Letters, 202: 61-75.

Rohling, E.J., Foster, G.L., Grant, K.M., Marino, G., Roberts, A.P., Tamisiea, M.E. and Williams, F., 2014. Sea-level and deep-sea-temperature variability over the past 5.3 million years. Nature, 508: 477-482.

Rohling, E.J. and Hilgen, F.J., 1991. The eastern Mediterranean climate at times of sapropel formation: a review. Geologie en Mijnbouw, 70: 253-264.

Rohling, E.J., Marino, G. and Grant, K.M., 2015. Mediterranean climate and oceanography, and the periodic development of anocix events (sapropels). Earth-Science Reviews, 143: 62-97.

Rossignol-Strick, M., 1983. African monsoons, an immediate climate response to orbital insolation. Nature, 30: 446- 449.

Rossignol-Strick, M., 1985. Mediterranean Quaternary sapropels, an immediate response of the african monsoon to variation of insolation. Palaeogeography, Palaeoclimatology, Palaeoecology, 49: 237-263.

Rossignol-Strick, M., 1987. Rainy periods and bottom water stagnation initiating brine accumulation metal concentrations: 1. the Late Quaternary. Paleoceanography, 2: 333360.

Rossignol-Strick, M., Nesteroff, W., Olive, P. and Vergnaud-Grazzini, C., 1982. After the deluge, Mediterranean stagnation and sapropel formation. Nature, 295: 105-110.

Roucoux, K.H., Tzedakis, P.C., de Abreu, L. and Shackleton, N.J., 2006. Climate and vegetation changes 180,000 to 345,000 years ago recorded in a deep-sea core off Portugal. Earth and Planetary Science Letters, 249(3): 307-325.

Ruddiman, W.F., 1971. Pleistocene sedimentation in the equatorial Atlantic: stratigraphy and faunal paleoclimatology. Geological Society of America Bulletin, 82(2): 283-302.

Ryan, W.B.F., 1972. Stratigraphy of Late Quaternary sediments in the eastern Mediterranean. In Stanley, DJ, ed, The Mediterranean Sea: A natural sedimentation laboratory: 149169. Stroudsburg, Pennsylvania, Dowden, Hutchinson and Ross. 
Sánchez Goñi, M.F., Eynaud, F., Turon, J.L. and Shackleton, N.J., 1999. High resolution palynological record off the Iberian margin: direct land-sea correlation for the Last Interglacial complex. Earth and Planetary Science Letters, 171(1): 123-137.

Sánchez Goñi, M.F., Landais, A., Fletcher, W.J., Naughton, F., Desprat, S. and Duprat, J., 2008. Contrasting impacts of Dansgaard-Oeschger events over a western European latitudinal transect modulated by orbital parameters. Quaternary Science Reviews, 27(11-12): 1136-1151.

Schmiedl, G., Pfeilsticker, M., Hemleben, C. and Mackensen, A., 2004. Environmental and biological effects on the stable isotope composition of recent deep-sea benthic foraminifera from the western Mediterranean Sea. Marine Micropaleontology, 51(12): $129-152$.

Scrivner, A.E., Vance, D. and Rohling, E.J., 2004. New neodymium isotope data quantify Nile involvement in Mediterranean anoxic eposides. Geology, 32(7): 565-568.

Shackleton, N.J., Hall, M.A. and Vincent, E., 2000. Phase relationships between Millennial Scale Events 64,000 to 24,000 Years Ago. Paleoceanography, 15: 565-569.

Shaw, H.F. and Evans, G., 1984. The nature, distribution and origin of a sapropelic layer in sediments of the Cilicia Basin, northeastern Mediterranean. Marine Geology, 61: 1-12.

Siani, G., Paterne, M., Michel, E., Sulpizio, R., Sbrana, A., Arnold, M. and Haddad, G., 2001. Mediterranean sea surface radiocarbon reservoir age changes since the Last Glacial Maximum. Science, 294: 1917-1920.

Sierro, F.J., Ledesma, S., Flores, F.J., Torrescusa, S. and del Olmo, W.M., 2000. Sonic and gamma-ray astrochronology: Cycle to cycle calibration of Atlantic climatic records to Mediterranean sapropels and astronomical oscillations. Geology, 28(8): 695-698.

Sømme, T.O., Piper, D.J., Deptuck, M.E. and Helland-Hansen, W., 2011. Linking onshoreoffshore sediment dispersal in the Golo source-to-sink system (Corsica, France) during the Late Quaternary. Journal of Sedimentary Research, 81(2): 118-137.

Stuiver, M. and Reimer, P.J., 1993. Extended ${ }^{14} \mathrm{C}$ data-base and revised Calib $3.0{ }^{14} \mathrm{C}$ age calibration program. Radiocarbon, 35: 215-230.

Svensson, A. et al., 2008. A 60,000 year Greenland stratigraphic ice core chronology. Climate of the Past, 4: 47-57.

Toucanne, S. et al., 2012. A 130,000-year record of Levantine Intermediate Water flow variability in the Corsica Trough, western Mediterranean Sea. Quaternary Science Reviews, 33: 55-73.

Trauth, M.H., Larrasoaña, J.C. and Mudelsee, M., 2009. Trends, rhythms and events in PlioPleistocene African climate. Quaternary Science Reviews, 28: 399-411.

Trigo, I.F., Bigg, G.R. and Davies, T.D., 2002. Climatology of cyclogenesis mechanisms in the Mediterranean. Monthly Weather Review, 130(3): 549-569.

Trigo, I.F., Davies, T.D. and Bigg, G.R., 1999. Objective climatology in the Mediterranean region. Journal of Climate, 12: 1685-1696.

Tuenter, E., Weber, S.L., Hilgen, F.J. and Lourens, L.J., 2003. The response of the African summer monsoon to remote and local forcing due to precession and obliquity. Global and Planetary Change, 36: 219-235.

Tzedakis, P.C., 2007. Seven ambiguities in the Mediterranean palaeoenvironmental narrative. Quaternary Science Reviews, 26: 2042-2066.

Tzedakis, P.C., Hooghiemstra, H. and Pälike, H., 2006. The last 1.35 million years at Tenaghi Philippon: revised chronostratigraphy and long-term vegetation trends. Quaternary Science Reviews, 25(23-24): 3416-3430.

Tzedakis, P.C., McManus, J.F., Hooghiemstra, H., Oppo, D.W. and Wijmstra, T.A., 2003. Comparison of changes in vegetation in northeast Greece with records of climate 
variability on orbital and suborbital frequencies over the last 450000 years. Earth and Planetary Science Letters, 212(1-2): 197-212.

Tzedakis, P.C., Pälike, H., Roucoux, K.H. and De Abreu, L., 2009. Atmospheric methane, southern European vegetation and low-mid latitude links on orbital and millenial timescales. Earth and Planetary Science Letters, 277: 307-317.

Valero, L., Garcès, M., Cabrera, L., Costa, E. and Saez, A., 2014. 20 Myr of eccentricity paced lacustrine cycles in the Cenozoic Ebro Basin. Earth and Planetary Science Letters, 408: 183-193.

Van Vugt, N., Langereis, C.G. and Hilgen, F.J., 2001. Orbital forcing in Pliocene-Pleistocene Mediterranean lacustrine deposits: dominant expression of eccentricity versus precession. Palaeogeography, Palaeoclimatology, Palaeoecology, 172: 193-205.

Vergnaud-Grazzini, C., Saliège, J.F., Urrutiager, M.J. and Iannace, A., 1990. Oxygen and carbon isotope stratigraphy of ODP Hole 653A and site 654: the Pliocene-Pleistocene glacial history recorded in the Tyrrhenian Basin (West Mediterranean), in K.A. Kastens, J. Mascle et al. (Eds), Proceedings of the Ocean Drilling Program. Volume 107: Scientific Results. Tyrrhenian Sea, 361-386, Ocean Drilling Program, College Station, TX.

Waelbroeck, C., Labeyrie, L., Michel, E., Duplessy, J.C., McManus, J.F., Lambeck, K., Balbon, E. and Labracherie, M., 2002. Sea-level and deep water temperature changes derived from benthic foraminifera isotopic records. Quaternary Science Reviews, 21(1-3): 295-305.

Wang, Y. et al., 2008. Millennial- and orbital-scale changes in the East Asian monsoon over the past 224,000 years. Nature, 451(7182): 1090-1093.

Weltje, G.J. and Tjallingii, R., 2008. Calibration of XRF core scanners for quantitative geochemical logging of sediment cores: Theory and application. Earth and Planetary Science Letters, 274: 423-438.

Wijmstra, T.A., Young, R. and Witte, H.J.L., 1990. An evaluation of the climatic conditions during the Late Quaternary in northern Greece by means of multivariate analysis of palynological data and comparison with recent phytosociological and climatic data. Geologie en Mijnbouw, 69: 243-251.

Williams, D.F., Thunell, R.C. and Kennett, J.P., 1978. Periodic freshwater flooding and stagnation of the Eastern Mediterranean Sea during the Late Quaternary. Science, 201: 252-254.

Xoplaki, E., Gonzalez-Rouco, F.J., Luterbacher, J. and Wanner, H., 2003. Mediterranean summer air temperature variability and its connection to the large-scale atmospheric circulation and SSTs. Climate Dynamics, 20: 723-739.

Zanchetta, G., Drysdale, R.N., Hellstrom, J.C., Fallick, A.E., Isola, I., Gagan, M.K. and Pareschi, M.T., 2007. Enhanced rainfall in the Western Mediterranean during deposition of sapropel S1: stalagmite evidence from Corchia cave (Central Italy). Quaternary Science Reviews, 26(3-4): 279-286.

Ziegler, M., Tuenter, E. and Lourens, L.J., 2010. The precession phase of the boreal summer monsoon as viewed from the eastern Mediterranean (ODP Site 968). Quaternary Science Reviews, 29: 1481-1490. 


\begin{tabular}{|c|c|c|c|c|c|}
\hline Stratigraphic Event & GDEC-4-2 - depth (cmbsf) & CALIB 7 Age (ka BP) & NGRIP GICC05 Age (ka BP) & GLT-syn Age (ka BP) & Summary Age (ka BP) \\
\hline Radiocarbon dates & 62.5 & $5.517^{*}$ & - & - & 5.517 \\
\hline Radiocarbon dates & 118.5 & $5.322 *$ & - & - & 5.322 \\
\hline Radiocarbon dates & 170.5 & 9.989 & - & - & 9.989 \\
\hline Radiocarbon dates & 198,0 & $8.926 *$ & - & - & 8.926 \\
\hline YD/Holocene transition & 230,0 & - & 11.70 & - & 11.7 \\
\hline Radiocarbon dates & 277.8 & 13.117 & - & - & 13.117 \\
\hline Radiocarbon dates & 347,0 & 13.954 & _- & _- & 13.954 \\
\hline Onset GI-1 / T.I & 360.5 & _- & 14.70 & _- & 14.7 \\
\hline Radiocarbon dates & 399.5 & 15.522 & - & - & 15.522 \\
\hline Radiocarbon dates & 589.5 & 18.160 & - & - & 18.160 \\
\hline Radiocarbon dates & 744.5 & 21.304 & - & - & 21.304 \\
\hline GI-2 peak & 860 & _- & 23.4 & _- & 23.38 \\
\hline Radiocarbon dates & 855.5 & 23.935 & - & _- & 23.935 \\
\hline Radiocarbon dates & 981 & 26.767 & _ & - & 26.767 \\
\hline Onset GI-3 & 1050 & _- & 27.82 & _- & 27.82 \\
\hline Onset GI-4 & 1110 & - & 28.92 & - & 28.92 \\
\hline Radiocarbon dates & 1179.5 & 32.359 & - & - & 32.359 \\
\hline Radiocarbon dates & 1274.5 & $25.545^{*}$ & - & - & 25.545 \\
\hline Onset GI-7 & 1300 & _- & 35.52 & _- & 35.52 \\
\hline Radiocarbon dates & 1363.5 & 37.516 & _- & _- & 37.516 \\
\hline Onset GI-8 & 1430.5 & - & 38.26 & - & 38.26 \\
\hline Radiocarbon dates & 1454.5 & 39.758 & _ & _- & 39.758 \\
\hline Onset GI-10 & 1498.5 & - & 41.5 & - & 41.50 \\
\hline Onset GI-11 & 1560 & - & 43.4 & - & 43.40 \\
\hline Onset GI-12 & 1675 & - & 46.9 & - & 46.90 \\
\hline Onset GI-14 & 1890 & _ & 53.85 & _- & 53.85 \\
\hline Onset GI-18 & 2340 & _ & - & 64.1 & 64.7 \\
\hline Onset GI-19 & 2685 & - & - & 71.7 & 71.7 \\
\hline Onset GI-20 & 2760 & - & - & 75.7 & 75.7 \\
\hline
\end{tabular}




\begin{tabular}{|c|c|c|c|c|c|}
\hline Onset GI-21 / MIS 5a & 2960 & - & - & 83.7 & 83.7 \\
\hline Onset MIS5b & 3090 & - & - & 90.7 & 90.7 \\
\hline Onset MIS5c & 3345 & - & - & 109.8 & 109.8 \\
\hline Mid-MIS5d & 3398 & & & 111.3 & 111.3 \\
\hline Onset MIS5d & 3517 & & & 118 & 118 \\
\hline Mid-MIS5e (2) & 3585 & & & 122.9 & 122.9 \\
\hline Mid-MIS5e (1) & 3680 & & & 125.35 & 125.35 \\
\hline Onset MIS5e / T.II & 3840 & - & - & 131 & 131 \\
\hline Mid-MIS6 (2) & 4430 & - & - & 146.5 & 146.5 \\
\hline Mid-MIS6 (1) & 4850 & - & - & 151 & 151 \\
\hline Onset MIS6d & 5780 & - & - & 178.5 & 178.5 \\
\hline Onset MIS7a & 6290 & - & _ & 199 & 199 \\
\hline Onset MIS7c & 6888 & - & - & 217 & 217 \\
\hline Onset MIS7e / T.III & 7300 & - & - & 243 & 243 \\
\hline Mid-MIS8 & 7990 & - & - & 264.3 & 264.3 \\
\hline Onset MIS8 & 8380 & - & - & 280.5 & 280.5 \\
\hline Onset MIS9a & 8500 & - & - & 291.4 & 291.4 \\
\hline Onset MIS9b & 8690 & - & - & 298 & 298 \\
\hline Onset MIS9d & 8890 & - & - & 321 & 321 \\
\hline Onset MIS9e / T.IV & 9210 & - & - & 336 & 336 \\
\hline Mid-MIS-10 & 9490 & - & - & 351 & 351 \\
\hline Onset MIS10 & 10350 & - & - & 396.5 & 396.5 \\
\hline Mid-MIS11c (2) & 10520 & - & - & 413 & 413 \\
\hline Mid-MIS11c (1) & 10780 & - & - & 423 & 423 \\
\hline Onset MIS11e / T.V & 10988 & - & - & 431 & 431 \\
\hline Mid-MIS12 & 11550 & - & - & 460.5 & 460.5 \\
\hline Onset MIS13a & 12010 & - & - & 495.5 & 495.5 \\
\hline Onset MIS13b & 12190 & - & - & 520.5 & 520.5 \\
\hline Base GDEC-4-2 (MIS14) & 12510 & _ & _ & 542.8 & 542.8 \\
\hline
\end{tabular}




\begin{tabular}{llllllll}
\hline Core number & Depth & Material & Lab code & \multicolumn{2}{l}{ Corrected ${ }^{14}$ C Cal BP age } & Cal BP age & Data origin \\
& (cmbsf) & & & age (yr BP) & ranges (2 $\sigma)$ & median probability & \\
\hline GDEC-4-2 & 62,5 & bulk planktic & Poz-40548 & $4760 \pm 35$ & $5,458-5,588$ & 5517 & this study \\
GDEC-4-2 & 118,5 & bulk planktic & Poz-40549 & $4600 \pm 35$ & $5,373-5,461$ & 5322 & this study \\
GDEC-4-2 & 170,5 & bulk planktic & Poz-33942 & $8860 \pm 50$ & $9,760-10,172$ & 9989 & this study \\
GDEC-4-2 & 198 & bulk planktic & Poz-40550 & $8050 \pm 50$ & $8,746-9,090$ & 8926 & this study \\
GDEC-4-2 & 277,8 & bulk planktic & Poz-40590 & $11250 \pm 70$ & $12,995-13,272$ & 13117 & this study \\
GDEC-4-2 & 347 & bulk planktic & Poz-40591 & $12100 \pm 60$ & $13,773-14,118$ & 13954 & this study \\
GDEC-4-2 & 399,5 & bulk planktic & Poz-40593 & $12980 \pm 70 *$ & $15,269-15,776$ & $15522 *$ & this study \\
GDEC-4-2 & 589,5 & bulk planktic & Poz-40551 & $14940 \pm 80$ & $17,933-18,373$ & 18160 & this study \\
GDEC-4-2 & 744,5 & bulk planktic & Poz-40552 & $17620 \pm 90$ & $20,986-21,613$ & 21304 & this study \\
GDEC-4-2 & 855,5 & bulk planktic & Poz-40554 & $19890 \pm 120$ & $23,605-24,253$ & 23935 & this study \\
GDEC-4-2 & 981 & bulk planktic & Poz-40555 & $22470 \pm 240$ & $26,179-27,298$ & 26767 & this study \\
GDEC-4-2 & 1179,5 & bulk planktic & Poz-40594 & $27980 \pm 250$ & $31,572-33,124$ & 32359 & this study \\
GDEC-4-2 & 1274,5 & bulk planktic & Poz-40595 & $21270 \pm 350$ & $24,600-26,167$ & 25545 & this study \\
GDEC-4-2 & 1363,5 & bulk planktic & Poz-40597 & $33300 \pm 500$ & $36,272-38,674$ & 37516 & this study \\
GDEC-4-2 & 1454,5 & bulk planktic & Poz-40598 & $35200 \pm 600$ & $38,535-41,072$ & 39758 & this study \\
\hline
\end{tabular}




\section{Figure}

Click here to download high resolution image

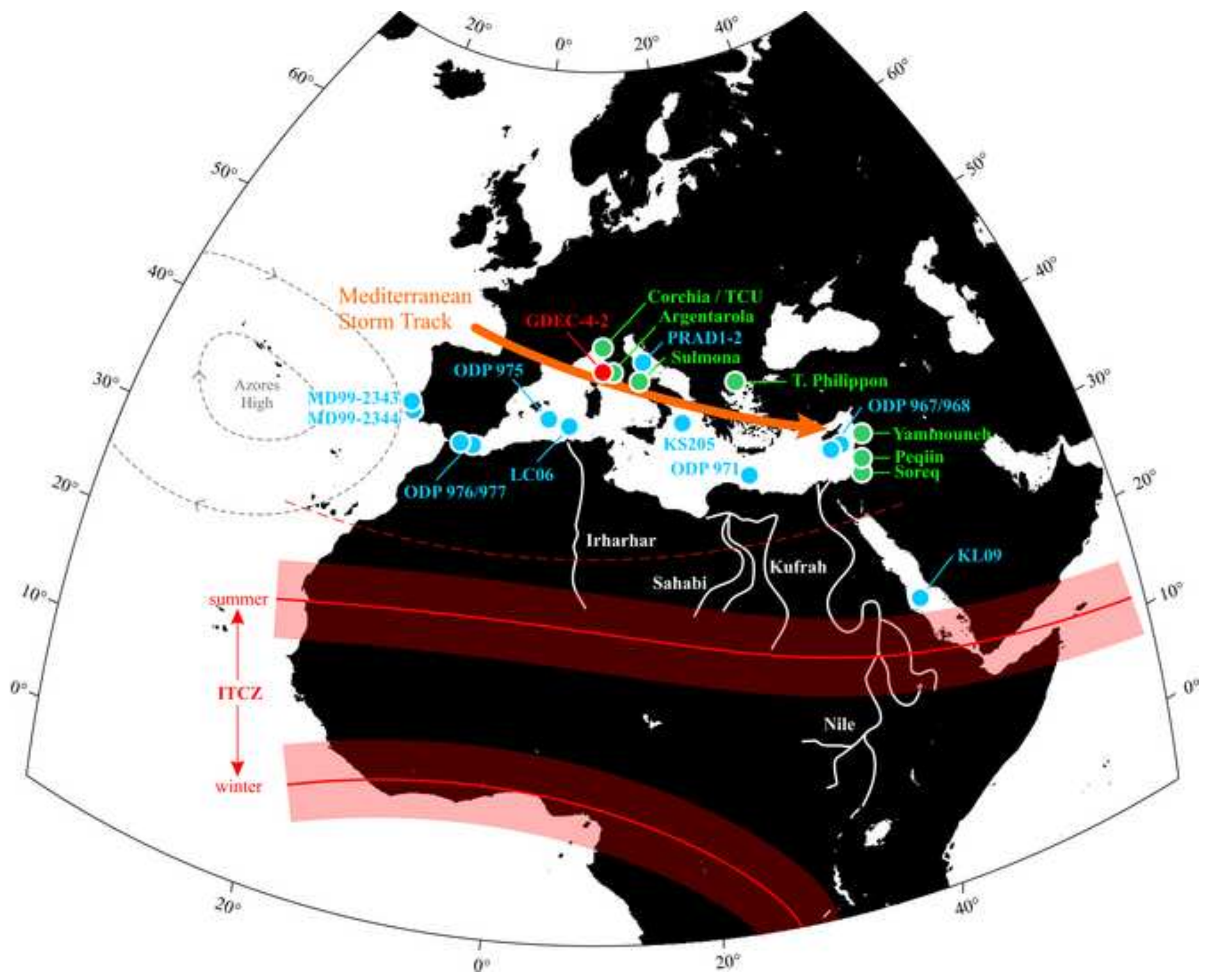




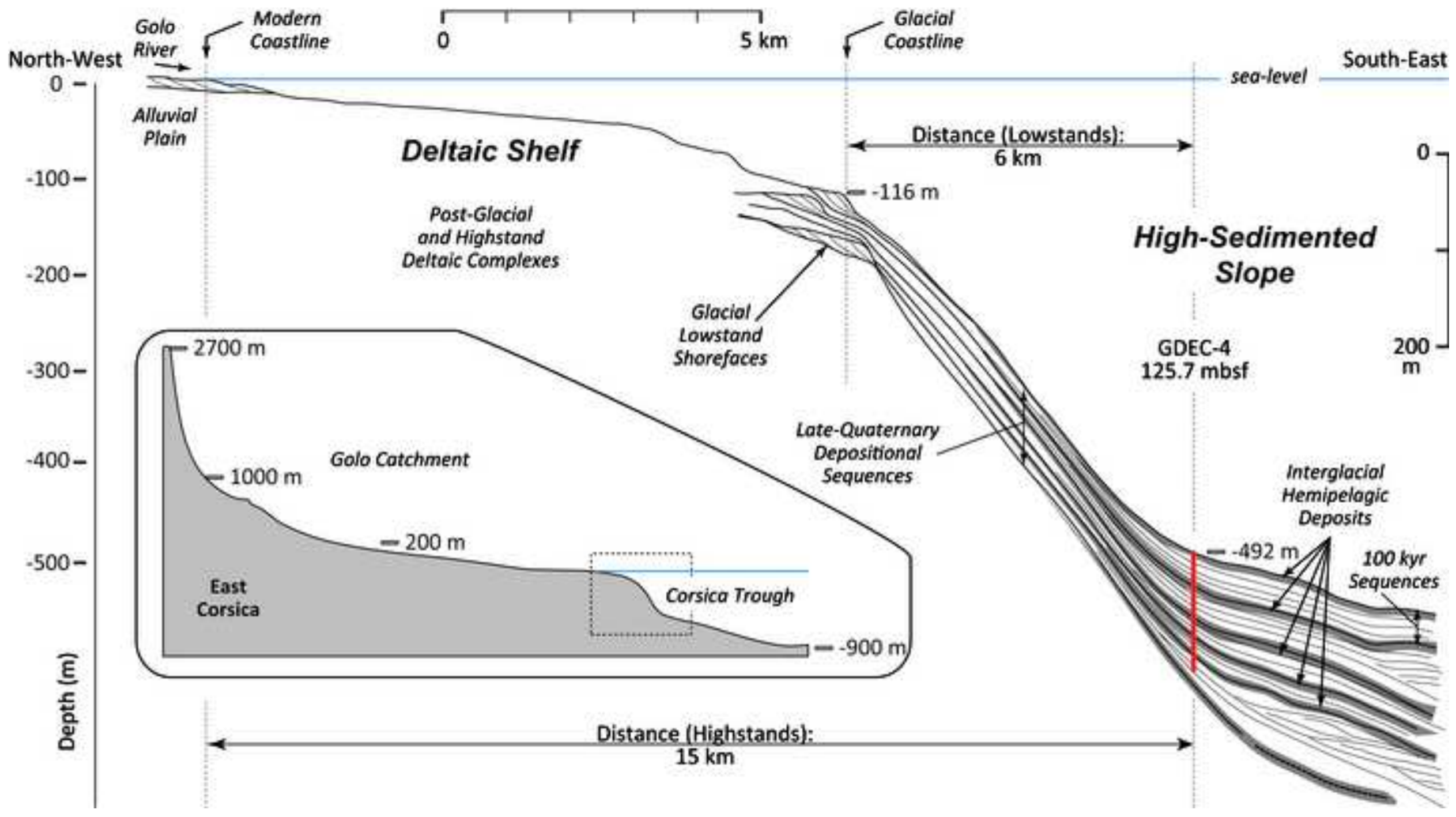




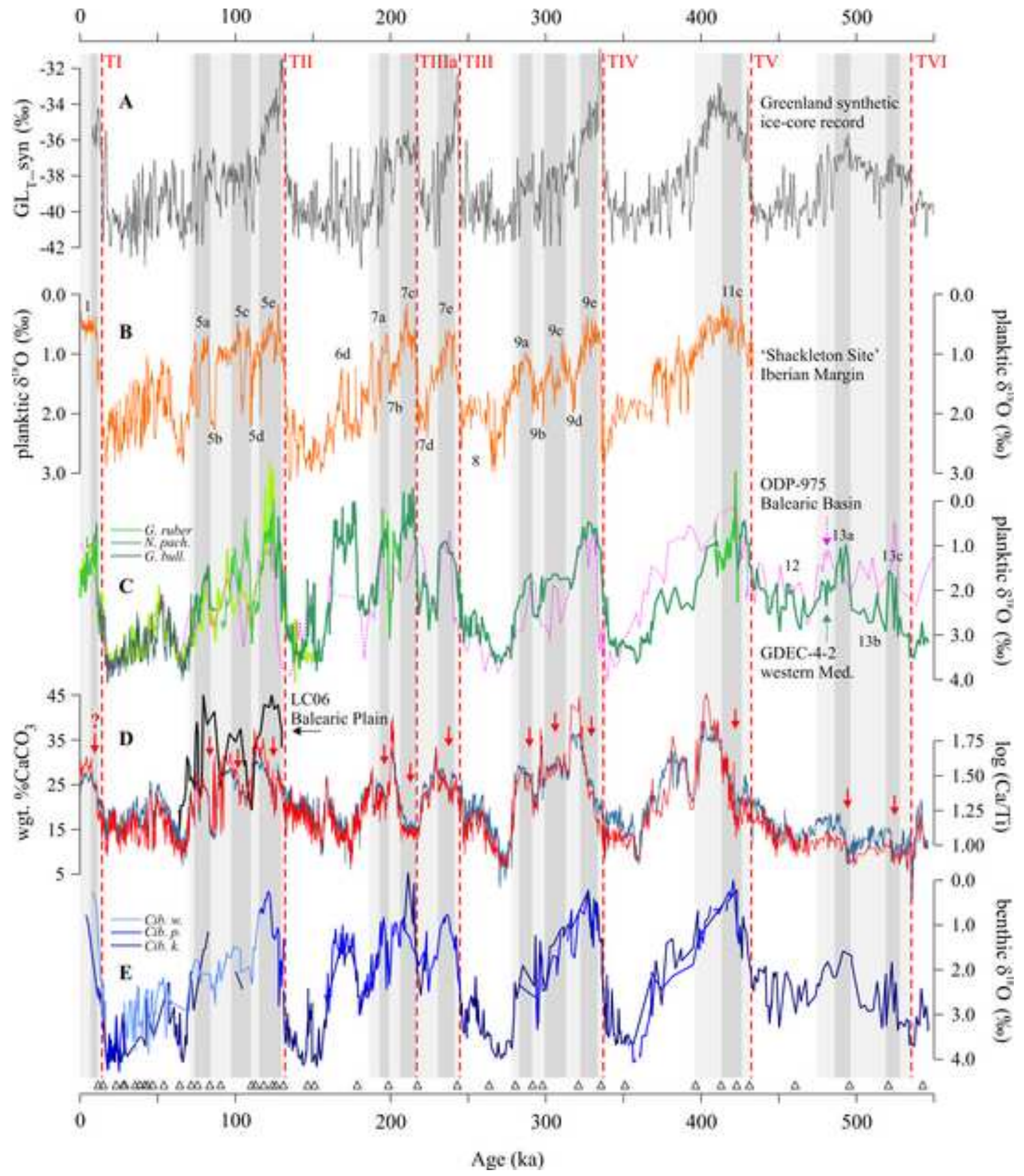

Age (ka) 
Click here to download high resolution image

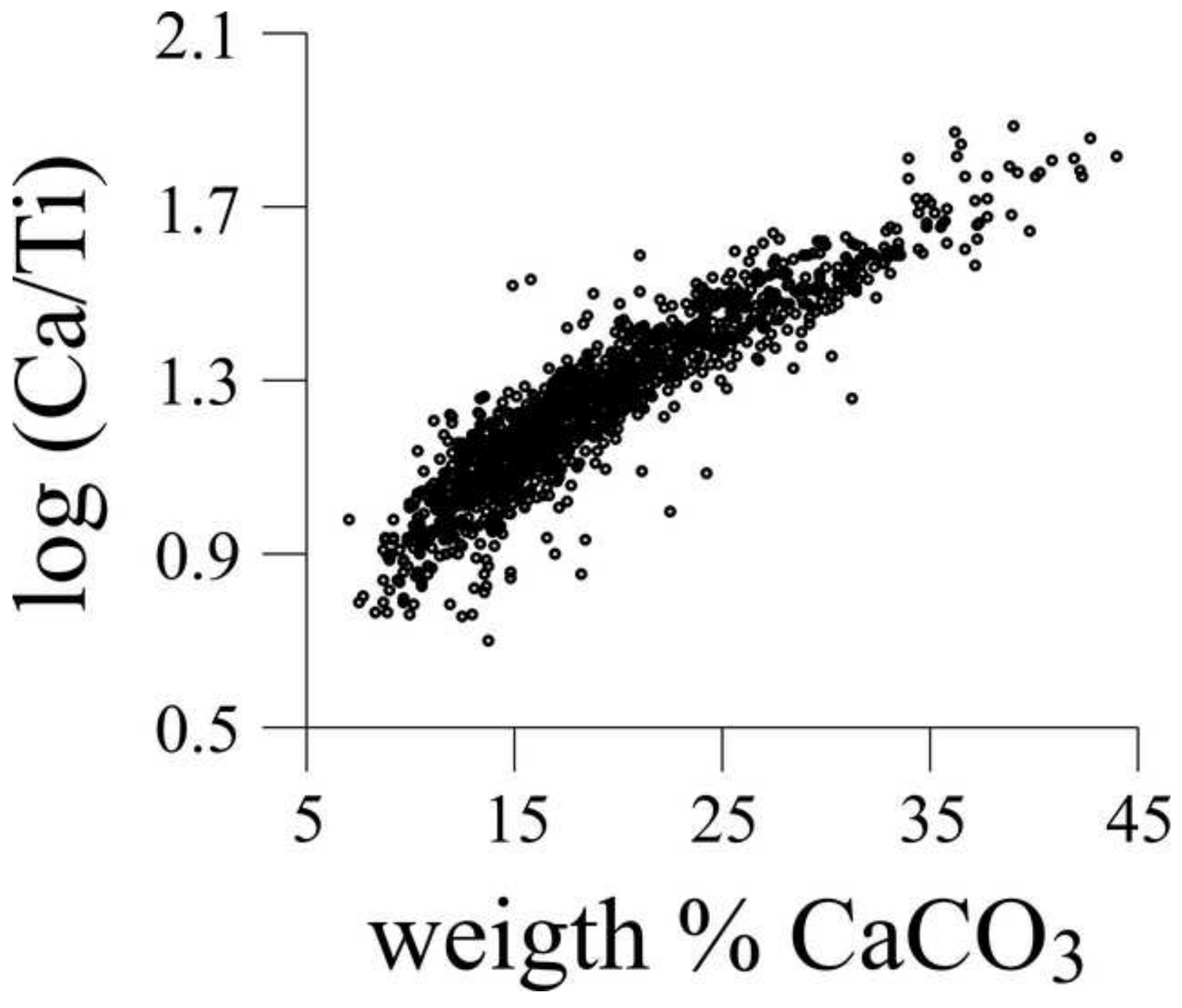




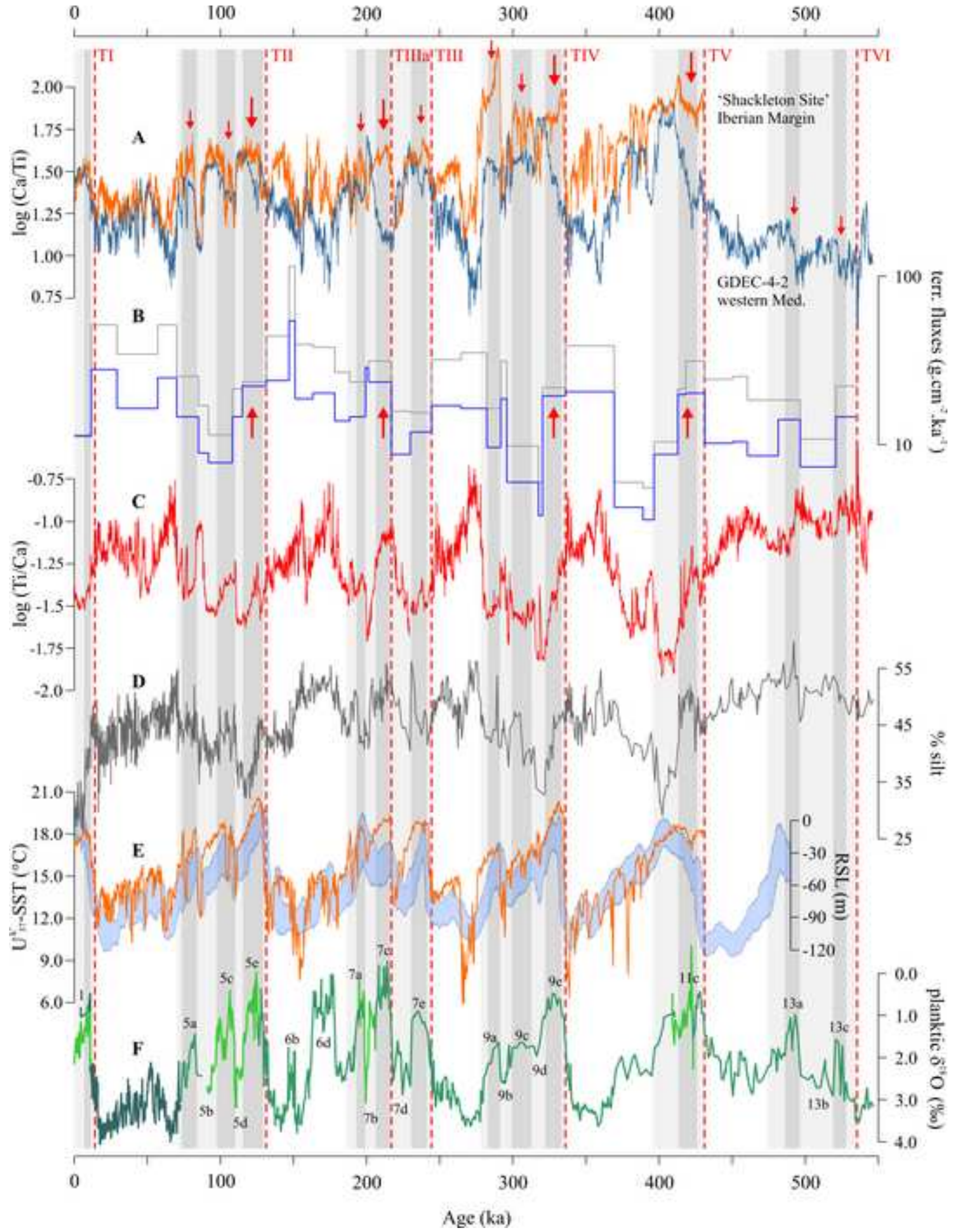

Age (ka) 

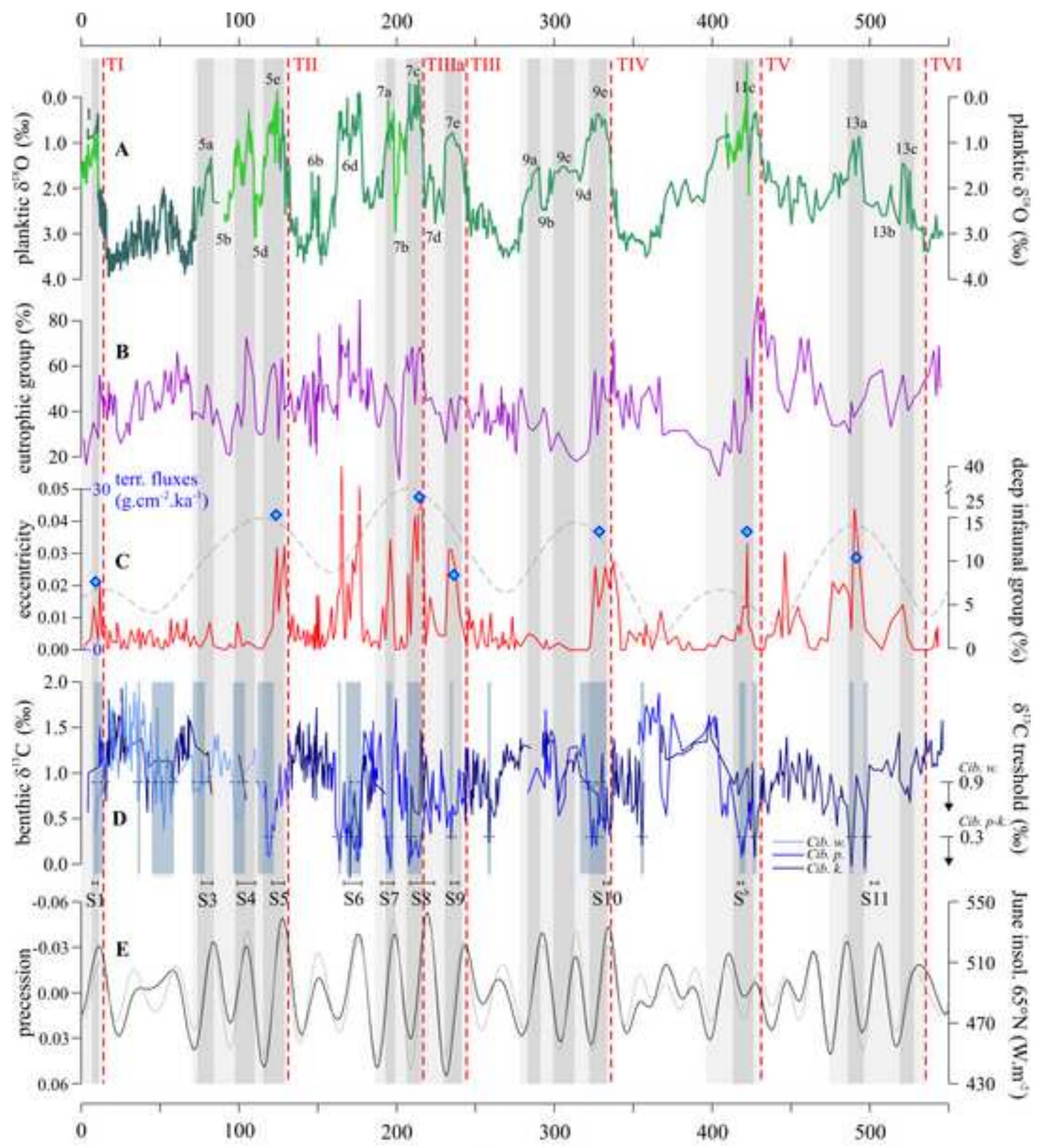

Age (ka) 

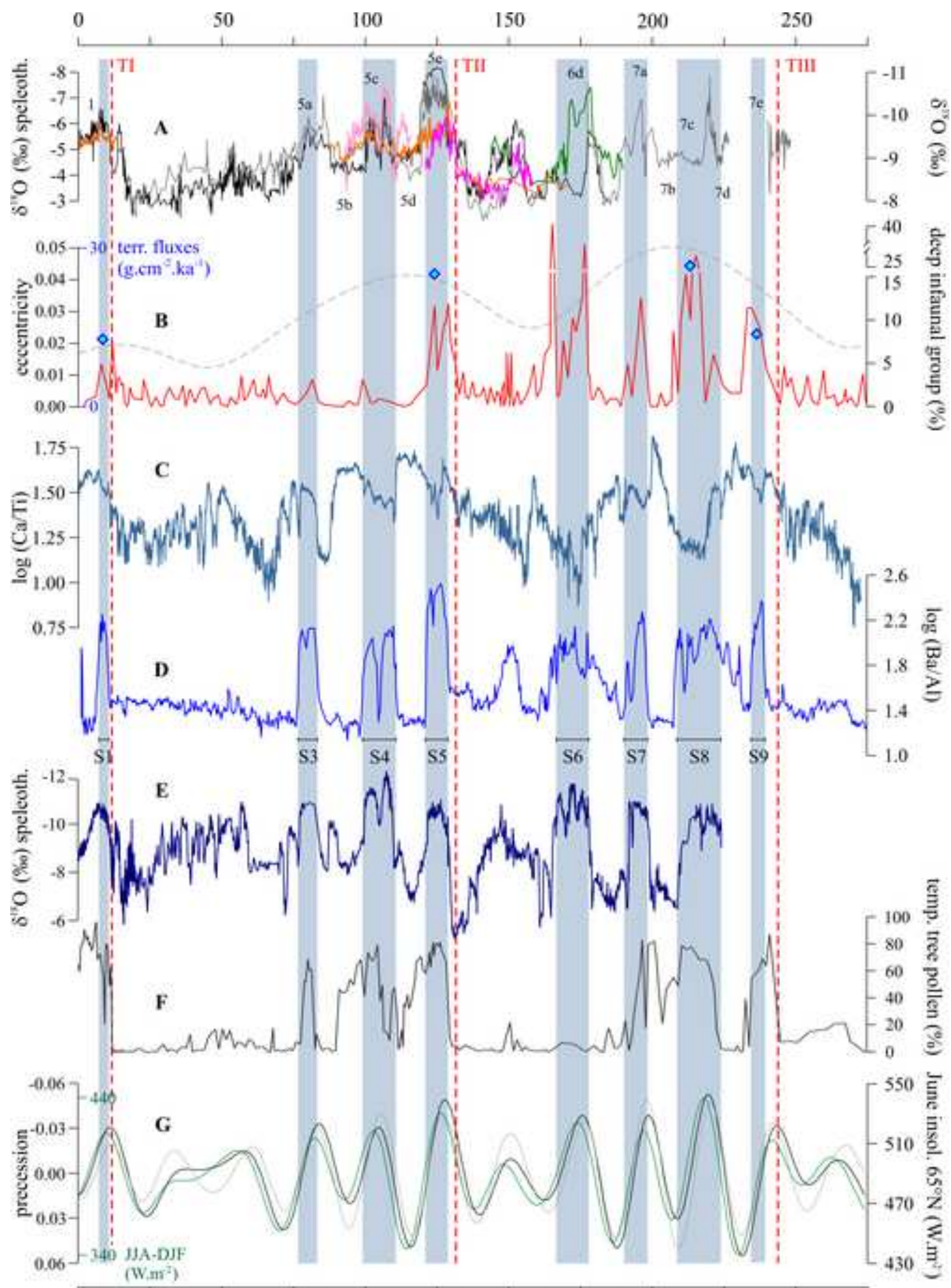

50

100

150

200

250

Age (ka) 


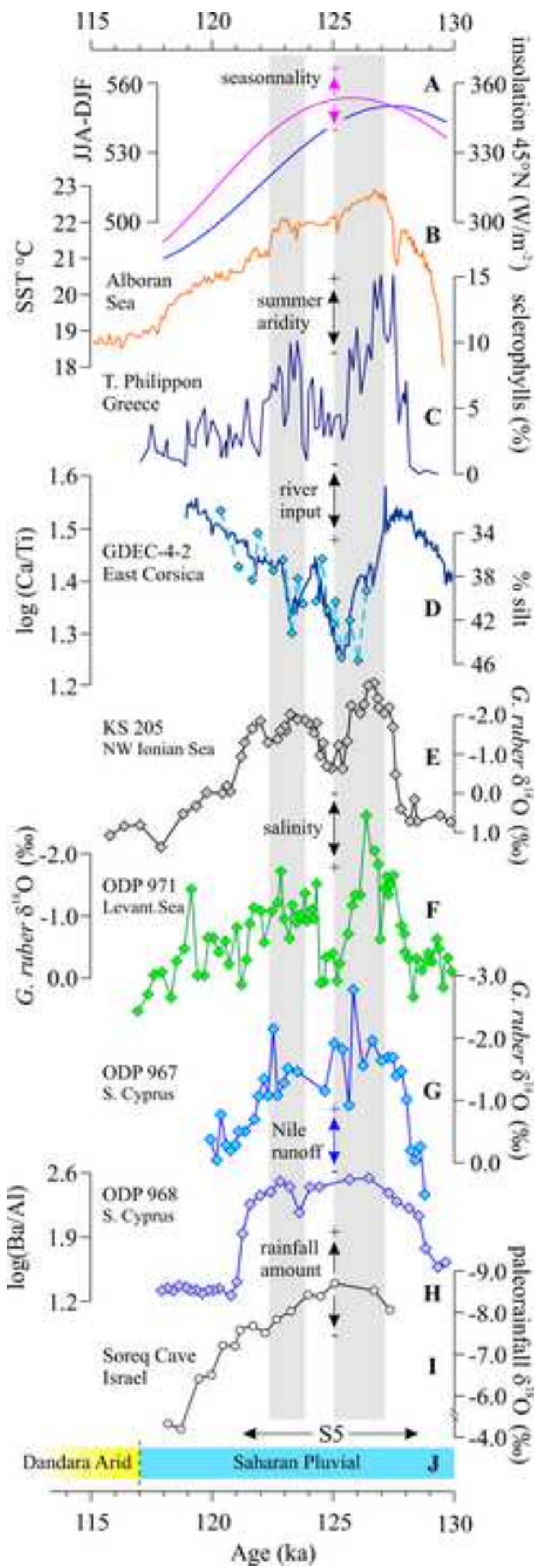

